Western University Scholarship@Western

1973

\title{
Changing Income Distribution under Development: Colombia
}

R.A. Berry

Follow this and additional works at: https://ir.lib.uwo.ca/economicsresrpt

Part of the Economics Commons

Citation of this paper:

Berry, R. A.. "Changing Income Distribution under Development: Colombia." Department of Economics Research Reports, 7306. London, ON: Department of Economics, University of Western Ontario (1973). 
$\Delta$

$\stackrel{8}{\leftrightarrow}$

Research Report 7306

CHANGING INCOME DISTRIBUTION UNDER

DEVELOPMENT: COLOMBIA

by

R. A. Berry

March, 1973 
CHANGING INCOME DISTRIBUTION UNDER

DEVELOPMENT: COLOMBIA

Many less developed countries have during the post World War II period achieved what are in historical terms quite respectable rates of growth of total output, and even of output (and income) per capita; while aspirations may fairly systematically outpace achievements in some countries, evaluations of economic performance must more or less disregard this factor, important as it may be from a political or social point of view. The charge is heard with increasing frequency, however, that successful growth has been characterized by worsening distribution, stable or even declining incomes for lower income members of the labour force, burgeoning urban slums filled with people who were "expelled" from stagnant and archaic agricultural sectors (or from ones whose pattern of modernization involved labour saving technological change), rapid population growth accentuating all the problems of labour surplus, and so on. Since very few countries have sufficient information even as far back as 20 or 25 years to provide effective bases of comparison with the more recent and more abundant information available to trace out present-day income distributions, most judgments with respect to trends in income distribution are of necessity impressionistic.

Fears that the distribution may be worsening seem well enough grounded, given the generally accepted belief that during the growth process of the now developed countries they passed through stages of worsening income distribution before reaching a subsequent stage of improvement associated with the approach of economic maturity. Many students of the growth process suggest that this worsening-bettering sequence may be necessary, since the 
high profit share linked to a skewed family or personal income distribution is likely to be the source of savings which fuel the growth. Some other more complicated models of development come to the same conclusion. It is indeed a pessimistic conclusion, since with the greater communications which permit the poor to ascertain how the rich live and in most cultures decrease the acceptance of great inequalities in income, the greater political activization in the masses, and so on, it seems hard to believe that the extent of economic inequality which seems to have characterized the industrial revolution periods of some now developed countries could be repeated, let alone that it should be repeated. On the other hand, there is the fear that, as it becomes necessary to redistribute income in an "extra-1abourmarket" fashion in order to prevent explosions, the ways in which this redistribution occurs will be such as to create disincentives and inefficiencies in the system and help to slow its growth down to unacceptable levels. This study attempts to piece together information of diverse sorts to trace out some features of the income distribution trends in Colombia during the last 30 or 40 years. Some attempt is made also to check the consistency of various alternative hypotheses which might explain the observations.

\section{Methodology}

Conceptually one hopes to study changes in income distribution using good quality surveys corresponding to different points of time, surveys involving comparable and appropriate definitions, and sufficiently rich in detail to permit testing a variety of hypotheses with respect to the mechanisms determining whatever changes are observed. Such a data base will remain an unrealizable dream for some time in most Latin-American countries, 
and Colombia is no exception. While four or five attempts have been made, at different points of time, to estimate distribution, ${ }^{1}$ only one has sufficient detail and appropriateness of methodology to lend it much confidence as a description of the distribution at that point of time (1964); among the other studies methodology is either too crude, insufficiently spelled out, or incomparable with the 1964 study to permit useful over time comparisons of this sort. ${ }^{3}$ Under the actual data conditions, over time comparisons of these surveys can at most serve as a check on other techniques. The information on which most weight will be placed in this study includes:

a) functional distribution over time; and

b) wage series for various groups of workers.

This, coupled with the information on changes in the occupational and sectoral structure over time, permits some appraisal of a) changes in the overall personal or family income distribution and b) with somewhat greater precision, changes in the distribution of labour income. A number of problems associated with differences between personal and family income, inclusion or non-inclusion of income not associated with the current production process, biasing effects of an increasing proportion of women in the labour force, and others are swept aside in order to paint the broad outlines of the picture. While the distribution of capital income is also of much

${ }^{1}$ See Miguel Urrutia, "Reseña de los Estudios de Distribucion de Ingresos en Colombia," Revista del Banco de la Republica, No. 508, Febrero, 1970.

${ }^{2}$ See Miguel Urrutia and Clara Elsa de Sandoval, "La Distribución de Ingresos Entre los Perceptores de Renta en Colombia--1964," Revista del Banco de la Republica, Julio, 1970.

3 For a discussion see a more detailed version of this paper, A. Berry, "Some Determinants of Changing Income Distribution in Colombia: 1930-1970," Yale Economic Growth Center Discussion Paper No. 137, March, 1972. 
interest, it is significantly harder to get at.

Reference is made to some of the possible mechanisms determining changes in income distribution, but information and careful analysis are not sufficiently far advanced to permit more than speculative hypotheses in this area at present.

The nature of the available data makes it convenient to partition the discussion in a number of respects; frequently it is possible to say with greater certainty what has happened within a given sector or time period than for the economy as a whole or over the whole time period considered-from some point in the 1930's to the present. In particular, separate information is available for the agricultural sector, so it is useful to distinguish agriculture and non-agriculture; in general much better information is available on the distribution of labour income than over all or for capital income; finally, reference of much of the available information to a number of benchmark years force the discussion to some extent into comparisons of periods delimited by those years. The basic conclusions of the analysis are: a) that income distribution in agriculture has worsened throughout the period since the mid-thirties, at which time data became available for the first time; b) that non-agricultural income distribution probably worsened from the mid-thirties until some time in the early 50's, then improved till some time in the mid-60's, and then tended to level off or possibly worsen again. Conclusion (b) is based primarily on and therefore particularly pertinent to the distribution of labour income; much less is known about the distribution of capital income and its relation to labour income. Since the hypothesis breaks down fairly clearly into two or three basic periods, the discussion will be organized along chronological lines. 

1930's to Early 1950's: Evidence

A considerable body of evidence suggests that overall personal or family distribution (always very bad) worsened from say 1930 until some time in the early 1950 's. 1

This period saw the struggling of the economy during the I atter part of the world depression in the 1930's; the advance of industry, given an initial impetus by the difficulties of importation during those years, and further stimulated during the war as capital goods were again difficult to import; and the rapid post-war industrial and overall growth associated with the balance of payments ease. The price of coffee started to rise rapidly in the late 40's and early 50's. Rural violence, present in substantial proportions in the $30^{\prime}$ s, exploded into the famous violencia in the late 40's and early 50's, and was undoubtedly one factor in accelerating rural to urban migration. Growth in income per capita was fairly continuous over the period, being particularly rapid during the last part of it; between 1945 and 1951-54, the average increase in income per member of the labour force was $5.1 \%^{2}$ per year, while output per member of the labour force was rising at $3.6 \%$. During the decade 1934-36 to 1944-46, income per member of the labour force grew less rapidly at $1.0 \%$ and output per member at $1.4 \%$. For the period as a whole income per capita grew at $2.8 \%$ and out put at $2.3 \%$. Major evidence of distribution worsening is the slower income growth

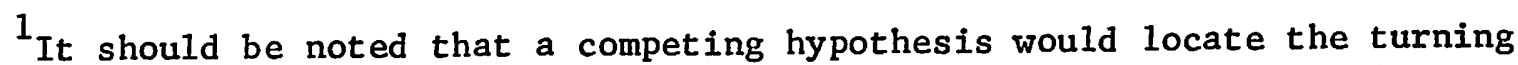
point from worsening to improving in the late fifties. This contention is of particular interest when only the urban sector is being considered. Udall's direct evidence on several low income occupations in Bogota would suggest this. His is the only data which separate out unskilled manufacturing workers, showing no clear rise until the early sixties. Average blue collar incomes began to rise rapidly in the early fifties, as is well known, but possibly these rises were limited to more skilled workers, or workers of large firms. (Udall's data were from classified ads, and it is not clear what bias this may create.) 
for unskilled labour than for other groups, especially in agriculture. ${ }^{1}$ (On diagram 1 are plotted relevant series for the major occupational categories for which information is available, and in Table 1 percent changes over specified periods are indicated.) In 1938 the landless or nearly landless group accounted for 47.5 percent of the total agricultural labour force; in in agriculture 1951 it was 55-57 percent. Whereas income per capita rose rather systematical1y over the whole post-1935 period, wages were lower in 1950 than in 1935 (having bottomed out in the early 1940's; the 1950-54 average was about $20 \% 1$ ower than in 1935, according to the figures. ${ }^{3}$ It seems probable, however, that these figures give a dowmward biased measure of real wage change over the period. 4

${ }^{1}$ slow income growth for agricultural workers characterized the whole period 1935 and on. Between 1935 and 1968, average income per capita in agriculture probably rose by about $150-175$ percent while the daily wage in agriculture appears not to have risen at all. (See, however, footnote 3.)

2 This figure includes family helpers in 1951; whether it does in 1938 is unclear but it seems probable; when they are excluded the figures are, of course, lower. Perhaps the most relevant ratio which can be derived from the census data is "obreros/employers + independent farmers + obreros." This was 50.5 in 1951 (excluding people not reporting their occupational position); the comparable figure for 1938 is not deducible from the census, since family helpers (assuming they are included at all) are not separated from paid workers. If the family helper/paid worker ratio had been constant between the two years, the above indicator would have been about 43 percent in 1938. Since a number of obreros are sons who will inherit land, these ratios overestimate the percent which might be thought of as a "permanently landless class". Further, most of them have some land, so the line defining "landless" and "landed" is a rather arbitrary one.

The percentages referred to for 1951 appear not to have changed significantly in subsequent years.

${ }^{3}$ See the author's, Development of the Agricultural Sector in Colontia, forthcoming, Chapter V.

4 Evidence from several countries, including Japan, suggests that wage rates may have been above their equilibrium levels (or simply over-reported) during the early years of the depression when prices were still falling or constant. The suggestion, in other words, is that wages lagged prices in the descent during the depression. (For a discussion of the Japanese case see Ryoshin, Minami, "The Turning Point in the Japanese Economy," The Quarterly Journal of Economics, Vol. LXXXII, Aug. 1968, p. 380. Unfortunately wage statistics are 





TABLE 1 (continued):

${ }^{a} 1936$ to 1953 ; these annual rates correspond to total real wage increases of $35 \%$ and $40 \%$, respectively.

${ }^{b} 1935$ to $1950-54$.

$c_{A}$ literal reading of the wage statistics indicates a decrease of $15.9 \%$ over the period 1935-37 to $1950-54$, i.e., of about $1 \%$ per year. It is argued elsewhere (Berry, The Development..., op. cit.) that the observations in the 1930 's are probably above equilibrium wages, since prices were falling and money wages could have lagged prices in this descent. The decrease of the GDP deflator over 1927-28 to 1935-37 was a little over $20 \%$, and that of the GNP deflator was probably about the same. It would seem implausible that the wage lag would account for a greater overestimate than $15 \%$, associated with falling prices, though there could also have been a wage lag simply associated with the fact that the real wage was falling. Perhaps a total overestimate of $20 \%$ would provide a sort of upper limit. This would imply a wage increase over the period of about $0.25 \%$ per year.

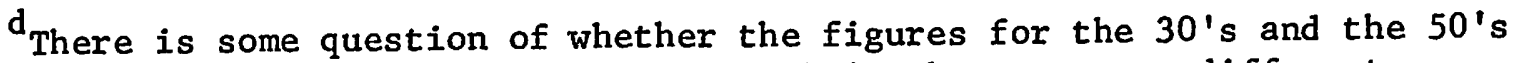
refer to the same groups, but it seems unlikely they are very different.

${ }^{\text {Refers to } 1953 .}$

${ }^{f}$ Assuming the reported daily wage and an average of 250 days worked per year.

$\mathrm{g}_{\text {Assumes }} 275$ days worked per year.

h Agricultural output divided by the labour force. (See Berry, The Development..., op. cit., Chapter V.)

$j_{\text {Net National Income per person, calculations based on the Cuentas }}$ Nacionales and my estimates of the labour force.

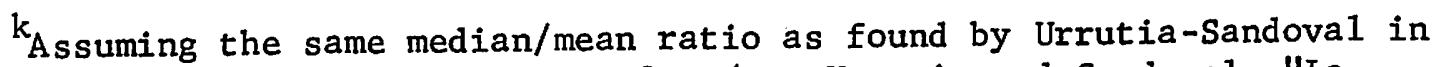
1964 , i.e., $4175 / 8410$ or 4.96 or 5.0 . (See Urrutia and Sandoval, "La Distribucion...," op. cit., p. 17.)



mefers to 1953 .

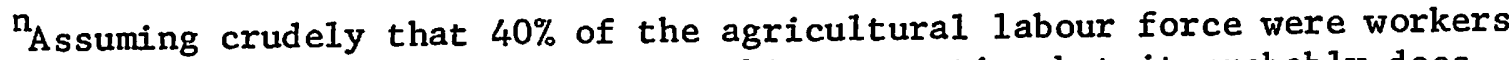
(col. 4); there is some imprecision in this assumption but it probably does not lead to a large bias in the estimate made. As explained elsewhere, there is no simple delineation of labourers and others. 
TABLE 1 (continued):

$P_{\text {Refers to } 1936 .}$

${ }^{\mathrm{q}}$ Provisiona1.

$r_{\text {Refers to } 1963-67}$

$s_{\text {Refers to }} 1969$; preliminary.

${ }^{t}{ }_{1964-66}$ to 1969 ; preliminary.

"Preliminary; based on rough splicing of DANE series to the authors series, which end in 1966.

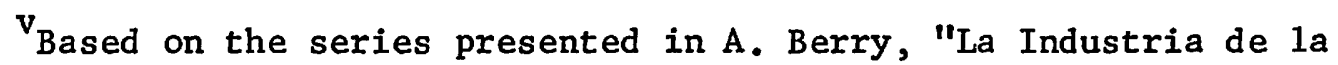
Construccion en la Decada de Los Sesenta," Economia Colombiana, Vo1. 92, April, 1972, tercer epoca.

${ }^{w}$ Calculated on the basis of cols. (1) and (2) and data on the share of the labour force in agriculture. The method of calculation underlying cols. (1) and (2) is somewhat different, with col. (1) probably having some upward bias relative to col. (2). Hence col. (9) may have a sizeable upward bias relative to col. (2); it seems unlikely, however, that these problems generate a significant bias in the growth rates calculated in col. (9). 
In agriculture, at least during this early period, little injustice is done to the facts by assuming two factors--homogeneous relatively unskilled labour and capital;(this is not to say that there were not many farmers whose income was due to their owning quantities of both factors, but rather that this sector, unlike manufacturing, did not have an important human capital component related to education or particular learned skills). Thus when the wage rate rose more slowly than average income this constituted a worsening of the distribution between labour and capital.

While wage statistics for the non-agricultural sector are scarce before the 1950's, it appears at least during the late 1940's and early 50's, that the distribution of labour income in manufacturing was worsening; a comparison of the 1945 and 1953 industrial censuses suggests that between those two years average blue collar wages rose by about 25 percent while average white collar wages were increasing by a phenomenal 100 percent.'

not available prior to 1935 in Colombia to verify this hypothesis, but the similarity of the pattern with Japan in particular does suggest this as the most likely interpretation for the wage rate decrease at this time. (This issue is discussed in greater detail in the author's The Development of the Agricultural sector in Colombia, Chapter II). Whether the decrease in the calculated real wage corresponds to a decrease in welfare of people at this time-as wages were finally bid down-is unclear; it may be that the wages reported during the previous years were accompanied by such employment difficulties as would indicate that the measured figures do not constitute a good indicator of real income. In any case, it seems likely that even when such employment difficulties are taken into account for the mid-thirties, it would be highly unlikely that an appropriate indicator would show as fast an increase in the agricultural real wage as characterized average agricultural incomes as a whole (3.7-4.2\% over the period 1935 to 1950-54 according to the author's estimates, op. cit., (hap. V) or average income per capita in the population as a whole.

${ }^{1}$ See Albert Berry, "Trends in Real Wages in Colombian Manufacturing and Construction," forthcoming. Note that this figure does not mean that white collar earnings rose by 100 percent for a given occupation. There was undoubtedly an upgrading of average education and training of the white collar workers in this period. (The number of engineers and certain other professionals probably rose marked1y). Still the increase for the representative occupation must have been substantial. 
The rapid growth of manufacturing during these years, and the particular focus on import substitution would be expected to contribute towards such a redistributive impact (see below). Such a comparison (white collar vs. blue collar wages) cannot be made for the universe of manufacturing firms before 1945; data from the firms reporting to DANE during the period 1936-1942 (between 400 and 1,000 according to the year) suggest approximately a 5 percent increase in real wages for blue collar workers and a 10 percent decrease for white collar workers. 1 This would be consistent with a pattern where the period of a rapidly widening white collar-blue collar differential began after World War II. This phenomenon was, as is well known, reversed beginning some time in the early or mid-1950's.

As indicated in Table No. 1 and Diagram 1, white-collar wages in manufacturing were far above the mean or median incomes of the economy at each point in time, so the rapid increase occurring for this period as a whole, and particularly in the post-war part of it implies, per se, a force towards worsening of the overall distribution. Blue collar workers in the factories included in the DANE surveys from which the above estimates were made also are above the median incomes, though a little below the mean; their $35-40 \%$ increase for the period as a whole was somewhat below the overall average; depending on what aspects of the income distribution one is primarily interested in, this could be a positive or a negative factor.

No good estimates of the purchasing power of manufacturing output ${ }^{2}$ over this time are available; physical output per person appears to have risen at about $4.7 \%$, and if one judges by the cost-of-living indices which include

${ }^{1}$ See ibid.

2 And hence of total income (labour plus capital) generated in manufacturing。 


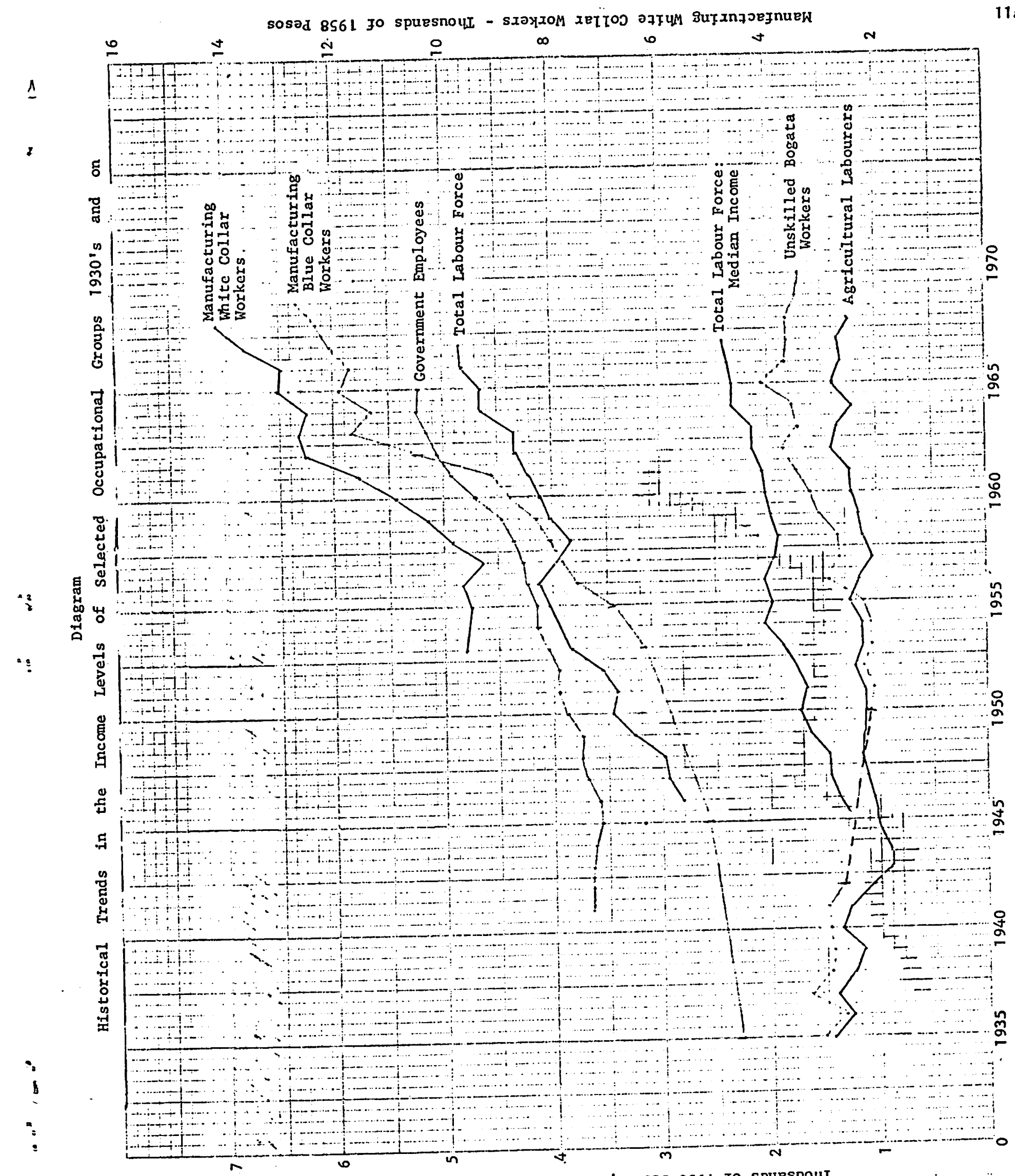


manufacturing items in the miscellaneous category, prices may have trended up somewhat, or at least been high relative to earlier periods. ${ }^{1}$ The fact that the increase in average wages (blue and while collar together) was somewhat less than the increase these figures suggest for average labour productivity, ${ }^{2}$ would suggest that the gross capital share rose somewhat and that income of capitalists in industry probably rose somewhat faster than wages, ${ }^{3}$ and certainly faster than average income of the total labour force, therefore contributing to a worsening of distribution. Earnings of artisan workers are not available for this period; it seems unlikely that they could have been changing rapidly, since there is little reason to believe that physical productivity was changing rapidly. ${ }^{4}$ The share of all industrial workers in certain artisan sectors was indeed decreasing, especially in the textile and clothing sectors where modern factory industry was cutting in rather heavily. This could

${ }^{1}$ David S. C. Chu, The Great Depression and Industrialization in Latin America, Ph.D Dissertation, Yale University, 1972, estimated that the relative price of non-traditional manufactures rose dramatically in the early thirties and remained high relative to the twenties at least through the midforties (where his study ends). Since the relative price of imported inputs rose less rapidly, the relative price of value added in manufacturing can be characterized as high during this period (see Chu, p. 82).

2 As shown in Table 1 , white collar wages rose at about the same rate as did average labour productivity, and blue collar wages somewhat slower; since the relative number of white collar workers was rising during this period, the average wages (white and blue together) rose at about 3.4\%--faster than a simple weighted average of the increases for the two categories.

3 How fast depreciation charges may have been rising is unclear, but it seems unlikely that their behaviour could imply net capital income rising less rapidly than labour income. Since average firm size was rising it seems unlikely that average capital income per capitalist was rising slower than average incomes as a whole.

${ }^{4}$ Or that the composition of output was altering significantly (as it has done in the last couple of decades). 
imply downward pressure on artisan incomes or upward pressure (via labour market competition). While overall no judgment can be made, it does seem unlikely that income per worker was rising as fast as the $2.8 \%$ which characterized the labour force as a whole during this period.

The movement of average wages of government employees (a category so heterogeneous ${ }^{1}$ that it is doubtful that it can be given much interpretation) is somewhat different (see Table A-1) from that of white collar workers in manufacturing; it seems not to have been increasing in the years preceding the end of World War II; a five year moving average of wages for all levels of government rises moderately over the succeeding decade (1945-55) and more rapidly in the following years. The movements are different for the different levels of government, in particular as between the national government and the other two levels. ${ }^{2}$ One interesting subgroup, the primary school teachers, underwent real wage declines during World War II, a rough constancy till some time in the early 50 's, then a rather rapid increase. The wage determination of both this subset of government employees and the category as a whole probably involves considerable non-market elements, so their remuneration

1 It includes professionals, teachers, police, street sweepers, and a host of other categories. A breakdown by blue collar/white collar would be useful but has not yet been effected. Alan Udall did study the wage trend for Bogota street sweepers, showing that taking 1937 and 1950-54 as end points an increase of about $10 \%$ was registered; but there were violent fluctuations in real wages and they were destined to fall more in the fifties before beginning an abrupt increase in the late fifties. (See Alan Uda11, Migration and the Labour Market; Bogota, Colombia, Yale Ph.D. Dissertation in progress, Chapter 2).

2 The figures here probably understate the real increase through failure to take adequate account of the increase in prestaciones sociales. Moving averages are used since nominal wages tend to change in steps in the government sector, with the result that real wages fluctuate rather violently and probably do not reflect short-run market phenomena. 
may not follow too closely the general

trends for people of comparable skill. 1

Persons in the employ of the three government levels rose from $2.4 \%$ to $3.1 \%$ of the labour force between 1938 and 1951 : assuming that a good number, apart from the teachers, required relatively little preparation, and skills were less important determinants of their employment, it is not necessarily surprising that they should not have shared in the rapid increase in white collar wages characterizing the manufacturing sector. ${ }^{2}$

In the construction sector data are scarcer and more difficult to interpret. Nevertheless a rather clear hypothesis emerges from a comparison of the scattered data on unskilled construction worker wages with the agricultural wage figures (See Table 2). It appears, over the 1ong run, that a) a relatively close relationship has prevailed between the two series, and $b$ ) that there has been a wage differential in favour of the urban (unskilled construction) worker; thus in the late 30 's the typical daily wage of a peon in Bogota appears to have been 20-40 percent higher than the daily wage of peons in the agricultural regions near Bogota (compare Cols. (1) and (3), Table 2). ${ }^{3}$

${ }^{1}$ A comparison with industrial wages suggests that an above equilibrium component of government employee salaries may have been rising, but serious consideration of this hypothes is would involve careful disaggregation of both groups.

2 An alternate explanation of the different behaviour would simply be the heterogeneity of the group considered; probably some sets of professionals didhave wage increases, but the different wage-setting procedure might even have prevented this.

3 Udall's study of the Bogota labour market indicates that average construction worker wages (not just obrero raso) rose about 23 percent during 1937 - 1963-4; over this period Cundinamarca agricultural wages rose 35-50 percent and those in Boyaca by about the same amount. (See Alan Udall, op. cit.) 





Table 2 (continued)

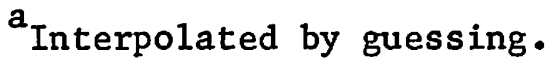

CDANE, Anuario General de Estadistica, 1966-67.

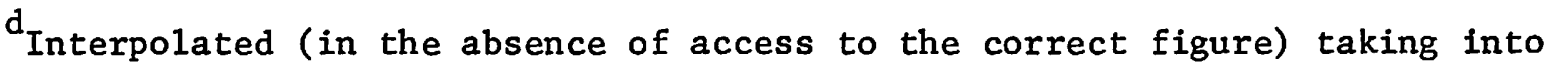
account an estimate of the change in the real agricultural wage between 1967 and 1968.

eDANE, Boletin Mensual de Estadistica No. 240, p. 32; equal weight was given to cold and hot regions.

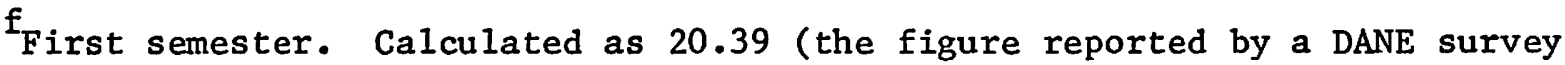
and excluding fringe benefits) plus an estimated 1.5 for those benefits.

Sources and Methodology:

For the years 1950 to $1958, \mathrm{Col}$. (1) is based on unpublished data kindly supplied by Robert Merrill; for subsequent years the lower figure of the CAMACOL series and the ICT series was chosen. In certain years in which ICT was paying the minimal wage, the CAMACOL figures were lower still and the assumption is that the market wage was in fact below the minimum wage at those times. In the last years the CAMACOL figures have been above those of ICT and also above figures suggested by data from CEDE, DANE, and experts in the field; for that reason we have accepted the ICT figures for 1965, 1966, and 1967. (It would be possible to verify more completely the consistency with the CEDE data during 1963-1966 if we knew the educational distribution among the unskilled workers, but we do not.) It should be noted that there is some difference of opinion as to whether real construction wages have risen over the last few years. The fact that the figures presented here for 1967-1970 were simply interpolated obviously implies that they are open to doubt. However the figures for 1965 and 1966 seem reasonably good, with no reason to believe they are overstated. And the 1971 figure is probably the most solid of all. Miguel Urrutia has argued that real wages for unskilled construction workers rose over 1968-1971, on the basis of CAMACOL data; this data has in the past involved a good deal of arbitrary guessing and so must be appraised carefully in this context. (See Miguel Urrutia M. "Problemas de Oferta de Factores de Produccion en 1a Nueva Estategia de Desarrollo," mimeo, 1972, p. 30.)

Cols. (2) and (3) are based on DANE information published in the Anuario General de Estadistica and/or the Boletin Mensual de Estadistica. For Col. (2) the cold and warm regions of Cundinamarca were weighted equally in the calculation.

Cols. (4) and (6) -(8) come from Berry, "The Development ... " op. cit., Ch.5, through 1965. (The original sources are the two just cited.). The specific sources for the subsequent years are cited in the footnotes. Col. (5) is Col. (1) deflated by the Bogota blue collar cost of living index constructed by DANE. 
The relationship appears to have become inverted in the early 50 's with the agricultural wage slightly higher, perhaps in part a result of the violencia. The typical long-run differential then reappeared in the late $50^{\prime} \mathrm{s}$ and since, fluctuating between 10 and 25 percent; it appears to have narrowed in the last five years, perhaps due to a slowdown in building, or perhaps to increasing efficiency of the labour market.

Some uncertainty attaches to this interpretation due to the fact that the wage figures presented in Col. (1) for 1935-1942 are public sector wages, while the post-1950 figures refer primarily to the private sector; in any case these Bogota public sector unskilled construction wages bore a fairly consistent relation to the Cundinamarca agricultural wages over the 1935-1942 period; the real construction wage showed no measurable change while that in agriculture fell a little. ${ }^{1}$ No figures are available between 1942 and 1950, but if it be assumed that the recorded public sector wages for the 1932-1942 period corresponded to the same skill level (or more generally to the same labour market) as those of the 1950-1970 series (not exclusively or even primarily public sector), then it would be concluded that the real wage fell by about 20 percent (from an index of

$1_{\text {The figures indicate that unskilled construction workers received }}$ a lower real wage in the late 30 's than in the early 30 's when sharp increases accompanied the rather rapid fall in prices but it seems probable, as noted above, that during both these periods the market was in disequilibrium; the rising real wages of the early 30 's were probably associated with the increasing employment problems, so that in a more general sense there may have been no increase in real income; conversely the decrease in the measured real wage probably was accompanied by improved employment possibilities and is therefore a misleading indicator when taken by itself. There are no figures for agricultural workers in the early $30^{\prime} \mathrm{s}$, but the similarity of pattern from the mid $30^{\prime} \mathrm{s}$ on between agricultural and construction wages, and in particular the parallel decline around the late $30^{\prime} \mathrm{s}$, hints strongly that real agricultural wages also rose during the early $30^{\prime}$ s, as prices fell. 
75 to one of 61 ) over the period. ${ }^{1,2}$ Thus the suggested 1935-50 wage movement clearly fits a "worsening distribution" pattern.

For the country as a whole, unskilled construction wage series are unavailable before 1950. A less close relationship between construction and agricultural wages would be expected at the national level due to different regional weightings for the two occupations, etc. But it is worth noting that the evidence available for the post-1950 period is consistent with a rather close tie. ${ }^{3}$ In view of this, it seems rather unlikely that the country-wide average unskilled construction wage differed markedly from that for Bogota over any extended period, especially since the two agricultural wage series have quite parallel movements. ${ }^{4}$ Consequently, it seems probable that construction wages in general suffered a decline in the 1930-50 period as a whole, or at least the 1935-50 period.

${ }^{1}$ Deflating by the Bogota blue collar cost of living series.

2 Meanwhile the Cundinamarca agricultural wage rose by 28 percent, about the same in cool climate regions as in the hot zones.

${ }^{3}$ As of 1971 (1st semester) construction wage differences across cities were not dramatic; (see Berry, "Some Determinants...." op. cit., Table A-2, which indicates that 7 of 10 cities sampled had average "helper" wages in the range 18.5-20.7 pesos per day and all but Cali [affected by the Pan American Games] had average "official" salaries between 25 and 35 pesos per day $J$ It seems probable that regional differences were greater in earlier years when geographic mobility was more limited, just as agricultural wages varied more by department in earlier years.

${ }^{4}$ It may be noted also, in connection with stability in wage structure that other construction workers thon the unskilled "obrero raso" category appear to have received about the same extent of wage increases as that group; the wage structure in the industry therefore has not altered much, at least as far as can be judged by Bogota data. 
For Bogota Udall's figures on wages in commerce fit the general pattern precisely; he finds a decrease between the years 1936 and $1954^{1}$ and a subsequent rather sharp increase to 1963-64. ${ }^{2}$ Maids' wages in Bogota, according to Uda11, rose rapidly over 1936-1945, fluctuated around the 1945 level till around 1950 when a sharp dip appeared, followed by a recovery which however only brought the wage up to its 1945 level around 1958-60; after this a substantial percentage increase has occurred, amounting over 1958-67 period to more than 25 percent. ${ }^{3}$

To summarize, the information for agricultural wages, blue collar manufacturing wages, construction wages, and commerce wages all show rather small or no increases from some point in the 30's to some point in the 50's. All clearly advanced less than the average income per member of the labour force. Maids' wages in Bogota, the weakest series in terms of methodology, are a partial exception--according to Udall's figures--depending on the particular period chosen. White collar workers in manufacturing and government both showed moderate or rapid increases at least over 1945-1955, suggesting

${ }^{1}$ The 1936-54 change is open to some question both because of the sma11 sample in both years and possible differences in the definition of "sma11," but also because of the fact that Udall had to assume the same ratio of average wages to average incomes in the two years, the two pieces of data apparently only being available together in 1954. See Udall, op. cit., p. ).

2 For 1963-64 Uda11 used wage data from CEDE's unemployment surveys to arrive at his estimate.

3 Udall obtained an observation every 2-4 years since 1945, based on classified advertisement data; although the methodology leaves room for some doubt, it is consistent over time. It is more doubtful that the calculated change over 1936-45 is accurate since the sources of information were different. One might speculate that Alfonso Lopez' social legislation had some impact on these wages though it would be surprising if a money wage series would catch much of it. 
a widening of the overall white collar-blue collar gap. ${ }^{1}$ There appears during this period to have been an excess supply of labour in a number of sectors with the corresponding downward impact on wages.

A glance at Diagram 1 will make it clear that there is some question as to how meaningful is the dividing line we have drawn here; several of the wage series had risen by 1950, but then fell between 1950 and the mid-1950's, this might be attributed to an exogenous increase in urbal labour supply related to the 'violencia'; if such relatively short-run phenomena are smoothed out it might be argued that the distinction between the two periods--before the mid-50's and after--is not a striking one. Still,it is true that if regression lines are fitted to most of the series discussed above, their slopes do tend to be lower than that calculated for the average income series over the period in question. As already indicated, this is in contrast to the events of a subsequent period (beginning some time in the early 50's and extending to some time in the early or mid-60's, according to the sector) during which the blue collar wages rose rapidly and white collar-blue collar gaps were narrowed. This period is discussed in more detail below.

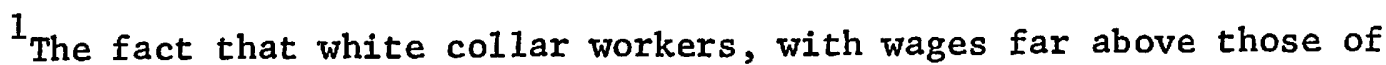
blue collar workers, were (and are) a growing minority of the total labour force would constitute a factor tending to increase inequality (e.g., in terms of the Gini coefficient) in the distribution of labour income, even if the ratio "white collar wage/blue collar wage" did not rise; the reasoning involved is that when the upper tail of the frequency distribution expands, the Gini coefficient rises. 
Though empirical information on capital incomes is scarce, theory and some observation would suggest that the import substitution policy begun in the $30^{\prime} \mathrm{s}$ but reaching substantial proportions especially after the war, raised these incomes in manufacturing (and commercial agriculture to some extent) and also led to greater inequality of the distribution of labour incomes. Import substitution may have been responsible also for the increasing ratio of white collar to blue collar incomes in manufacturing after World War II; almost certainly it was one factor working in this direction. Information on the capital share is shaky. In manufacturing it appears not to have changed much between 1944-45 and 1953; in 1953 the labour share of gross value added (at factor cost) appeared to be a little over 30 percent $^{1}$ a rough estimate based on $d \ni t \geqslant$ kindly made avail David Chu suggested a not very different labour share in 1944-45. 2 In agriculture an increase does appear to have occurred (the labour share seems clearly to have been falling) though it is unclear how much of it was associated with import substitution.

${ }^{1} 28.7$ percent using DANE's upward biased value added figures-not all of purchased in puts were subtracted out in DANE's calculations of value added.

2 Import substitution was occurring during the war as well as after it--in the former period it was a result of the restrictions on world trade associated with the conflict. One might not therefore have predicted any increase in the capital share in industry during this period (1945-53) but rather over say 1935-1950. Further, it must be noted that the overall capital share increasing impact of import substitution might have occurred primarily through changes in the relative size of different sectors, e.g., a decrease in relative importance of agriculture (which had at that time a relatively high labour share) and an increase in that of industry. 
Overall changes in the income distribution depend not only on relative changes in the incomes of occupational groups at different positions in the distribution, but to changes in their relative sizes. Clearly the major structural change during this period (and in subsequent ones) was the decreasing share of the agricultural relative to the total labour force. Since at the start of the period the agricultural sector encompassed about $65 \%$ of total labour force (mid-thirties), the sma11 but increasing size of the non-agricultural sector, with its substantially higher average income than that of agriculture, could have worked towards an overall worsening. 1 As of 1945, the average income in agriculture was probably about 35-40 percent of that in non-agriculture; in 1935 it was perhaps $30-35 \% .^{2}$ In 1964, the agricultural personal income distribution had about the same degree of inequality as the urban one when unemployed persons were included in the urban labour force. ${ }^{3}$ It is probable that the family distribution was more unequal in agriculture at this time; as suggested by the fact that when the unemployed were excluded from the urban

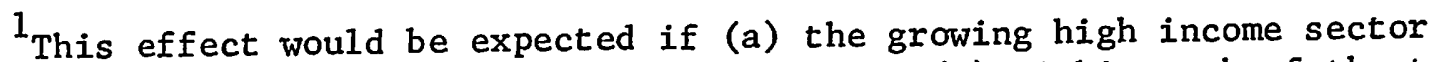
is considerably smaller than the other one and if (b) within each of the two groups into which the labour force was divided, everyone had the same income, or if the income distribution was at least as unequal in the growing sector as in the other one. The result would be expected for most but not all combinations of intragroup income distributions. In a case such as that discussed here, the observed sequence at best creates a likelihood of a worsening distribution, since not enough is known about the intrasectoral distributions to say more. The argument was used by Simon Kuznets in discussing the implications of the rural to urban labour force transfer. (See Simon Kuznets, "Economic Growth and Income Inequality," American Economic Review, Vol. XLV, No. 1, March 1955).

. 2 See A. Berry, The Development of the Agricultural Sector in Colombia, Ch. I, forthcoming.

${ }^{3}$ See Albert Berry y Alfonso Padilla, "La Distribucion de Ingresos Provenientes de la Agricultura en Colombia, 1960," in DANE Boletin Mensual de Estadistica, No. 234, Enero, 1971, p. xxi. The measure of inequality was the Gini coefficient. The urban distribution data on which the comparison is based are from Urrutia and Sandoval "La Distribucion de Ingresos....." op. cit. 
labour force, that distribution was less unequal than the agricultural one; since evidence suggests that a good share of the urban unemployed are members of relatively well-off families, it may be more appropriate to exclude them in making the comparison. ${ }^{1}$ Since the agricultural income distribution appears to have been worsening substantially over the period 1935-1964, whereas there is less evidence to that effect (see below) in non-agriculture, it may be speculated that the agricultural distribution was less skewed 30 or 40 years ago than that of non-agriculture. If this was the case, the gradually increasing share of people in the non-agricultural sector would be expected to worsen overall distribution both because of the difference in average incomes of the two sectors and because of the greater inequality per se in the non-agricultural distribution. (But see the reservation of footnote 1, p. 22).

A crude quantification of the effect of these factors on distribution in the period 1934-6 to 1950-4 may be obtained by assuming for each of agricultural wage earners, other agricultural labour force, and non agricultural labour force income is distributed in the same way (around a different mean) at the beginning of the period as at the end. ${ }^{2}$ The tentative conclusion of this exercise is that, if the assumptions underlying the calculation are not too far from being accurate, then distribution worsened over this period (see Table 8). The top deciles would have increased their share of the pie; the bottom deciles would have suffered a decrease.


thought of partly as a proxy for the "potential consumption" distribution. Even though these white collar unemployed may have no income their consumption may be relatively high.

${ }^{2} \mathrm{~A} 1$ thouth scattered information is available on income trends in some categories of the non-agricultural labour force, it would be difficult to piece it together in such a way as to "use" such information effectively. We limit ourselves here to the crude assumption of no change in distribution within the whole non-agricultural labour force. 
II Possible Improvements in Distribution Between the Early Fifties and the Mid-Sixties

While conclusions naturally remain somewhat speculative, the weight of evidence for the urban areas suggests an improvement beginning some time in the 50's and going through the mid-sixties; for the labour force as a whole this is less clear since it seems fairly certain that the distribution of income in agriculture continued to worsen during this period. ${ }^{1}$ We turn first to the non-agricultural sector。

For this post-1950 period, it is possible to use both estimates of functional income distribution and various wage and earnings series to try to build up a picture of how distribution has been changing. Functional distribution is a rather good indicator of personal or family distribution for certain of the non-agricultural sectors where independent workers are relatively unimportant, such as the factorysector in industry.

Before turning to the functional distribution, however, we review such earnings series as are available, comparing them to the average income per worker change, which for the period $1950-54$ to $1964-67$ was $1.9 \%$ per year. ${ }^{2}$

As noted above, blue collar wages in the factory industrial sector rose dramatically since the early 50's; average annual increase between 1953 and 1964-66 was 4.6\%, well above the overall urban sector average. This

${ }^{1}$ It is interesting to note, however, that Miguel Urrutia, working with average labour productivity of paid workers, independent workers and employers in the National Accounts' Sectors, found a decreased dispersion in 1964 relative to 1951 (see Miguel Urrutia, "Variacion Historica de la Distribucion de1 Ingreso en Colombia," mimeo.)

${ }^{2}$ Based on net national income at market prices per worker. When one uses income of families and non-profit institutions per worker, deflated by the private consumers goods price index, the indicated increase is about $2.3 \%$. The figure would be lower the more investment goods entered the deflator, since their price rose more rapidly than that of consumer goods. 
factor per se does not imply an improvement in income distribution, since average income in this category was above the urban mean at the beginning of the period and still farther above it at the end. Wages in smaller factories and income of artisan workers, meanwhile, rose less rapidly, although they still appear to have risen faster than urban incomes as a whole. They tended to be below the median urban income at the beginning of the period, so their growth may be thought of as contributing to a decrease in inequality. ${ }^{1}$ Finally, white collar incomes in industry rose much more slowly than those of blue collar workers, averaging an increase of about $2.2 \%$ over the period in question. 2

The evidence that urban distribution improved over this period, comes primarily from the lower income sectors of construction workers, workers in small scale commerce and--though with considerably less confidence in the figures--wages of maids. Wages of street sweepers in Bogota also fit the pattern, from the late fifties on; their rapid rise began later than for construction and manufacturing workers.

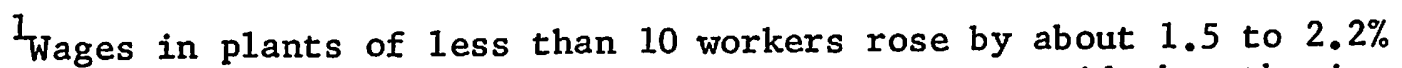
annually over 1953-1966. (See Table 3) This was more rapid than the increase in urban income/urban labour force, though very probably not above the average rate of increase of income offpersons in the urban labour force. (The first ratio referred to is pulled down by the arrival of many low income immigrants.)

2 The important piece of evidence, that the average white collar wage in manufacturing did not rise rapidly in the post-1953 period, could be misleading if the composition of this group changed over the period, e.g., if an increasing share of the people were messengers or other low wage subgroups. As of 1964 there were 11.3 thousand professionals, etc., 10.6 thousand "managers, administrators, etc.", 35.3 thousand office employees, and 14.6 thousand sales people, etc. in the manufacturing sector. (These 70 thousand may be compared to a total of 50.8 reported by the factory sector in 1964 as being white collar workers. There would be some such workers in the smaller firms excluded from the samples, but probably not too many.) In 1951 the comparable breakdown of the 35 thousand manufacturing sector white collar workers reported in the population census was: professionals, etc. 6.0 thousand; managers, administrators, etc. 11.0 thousand; office employees 11.9 thousand; and sales people 5.9 thousand. Other evidence has shown that the division between "managers, 
Table 3

Selected Real Annual Wage Series (1958 prices)

\begin{tabular}{|c|c|c|c|c|c|c|c|}
\hline \multirow{3}{*}{$\begin{array}{l}\therefore \\
\therefore \\
\text { Year }\end{array}$} & \multirow[b]{2}{*}{$\begin{array}{c}\text { Construction } \\
\\
\text { Unskilled } \\
\text { Construction } \\
\text { Workers } \\
\text { Bogota }\end{array}$} & \multicolumn{3}{|c|}{ Manufacturing } & \multicolumn{2}{|c|}{ Conmerce } & \multirow[b]{2}{*}{$\begin{array}{c}\text { Maids } \\
\\
\text { (Index } \\
1958= \\
100)\end{array}$} \\
\hline & & $\begin{array}{l}\text { Artisan } \\
\text { Manu fac- } \\
\text { turing } \\
\end{array}$ & $\begin{array}{c}\text { Plants of } \\
<5 \\
\text { Workers* }\end{array}$ & $\begin{array}{c}\text { Plants of } \\
<10 \\
\text { Workers }\end{array}$ & $\begin{array}{c}\text { Establish - } \\
\text { ments of }<5 \\
\text { Workers }\end{array}$ & $\begin{array}{c}\text { Food and Beverage } \\
\text { Stores with } \\
\text { Sale of } \\
<100,000 \text { per } \\
\text { Year ( } 1967 \text { pesos) }\end{array}$ & \\
\hline & $(1)$ & $(2)$ & (3) & (4) & $(5)$ & $(6)$ & (7) \\
\hline $\begin{array}{l}1950 \\
1951 \\
1952 \\
1953 \\
1954\end{array}$ & $\begin{array}{l}1091 \\
1048 \\
1122 \\
1067 \\
1075\end{array}$ & 2517 & & 2320 & $2000-2500$ & 1070 & \\
\hline $\begin{array}{l}1955 \\
1956 \\
1957 \\
1958 \\
1959\end{array}$ & $\begin{array}{l}1138 \\
1463 \\
1353 \\
1378 \\
1540\end{array}$ & & 2390 & & & & 100 \\
\hline $\begin{array}{l}1960 \\
1961 \\
1962 \\
1963 \\
1964\end{array}$ & $\begin{array}{l}1606 \\
1727 \\
1884 \\
1713 \\
1793\end{array}$ & 3129 & & & & & \\
\hline $\begin{array}{r}1965 \\
1966 \\
1967 \\
1968 \\
1969\end{array}$ & $\begin{array}{l}2071 \\
1843 \\
1810 \\
1810 \\
1735\end{array}$ & & $2820-3080$ & $2800-3060$ & 2900 & 1680 & 130 \\
\hline 1970 & 1708 & & & & & & \\
\hline & $\begin{array}{r}\text { * And less than } \\
\text { Sources and Me } \\
\text { Col. (1) is b } \\
\text { assuming } 2 \\
\text { Col. (2) is } \mathrm{f} \\
\text { Desarrollo } \\
\text { Cols. (3) and } \\
\text { factors fo } \\
\text { years sinc } \\
\text { turing, Ya } \\
\text { Cols. (5) and } \\
\text { Col. (5) t } \\
\text { between th } \\
\text { as a Socia } \\
\text { mimeo, p. } \\
\text { col. ( } 7) \text { is } \\
\text { Ph.D. diss }\end{array}$ & $\begin{array}{l}24,000 \text { pe } \\
\text { thodology: } \\
\text { ased on th } \\
75 \text { days pa } \\
\text { rom Miguel } \\
\text { Colombian } \\
\text { (4) are c } \\
\text { r the year } \\
\text { e 1962). } \\
\text { le Ph.D. d } \\
\text { (6) are b } \\
\text { he } 1954 \text { es } \\
\text { e two cens } \\
\text { 1 Problem } \\
98 \text {. } \\
\text { rom Alan U } \\
\text { ertation i }\end{array}$ & $\begin{array}{l}\text { os output. } \\
\text { nominal wa } \\
\text { id per year. } \\
\text { Urrutia and } \\
\text { " Revista d } \\
\text { lculations } \\
1966 \text { (to of } \\
\text { see John Tod } \\
\text { issertation, } \\
\text { ised on the } \\
\text { imated rang } \\
\text { ises. The e } \\
\text { in Colombia: } \\
\text { lall, Migra } \\
\text { progress. }\end{array}$ & $\begin{array}{l}\text { e series of } \\
\text { Clara Elsa } \\
\text { Planeacion } \\
\text { y the autho } \\
\text { set a bias } \\
\text {, Size of } \\
\text { 1972. } \\
\text { ommerce cen } \\
\text { is prelimi } \\
\text { timates of } \\
\text { Some Preli } \\
\text { ion and the }\end{array}$ & $\begin{array}{l}\text { Table 2, defla } \\
\text { illalba "E1 } \\
\text { y Desarrollo, } \\
\text {, making use } \\
\text { ntroduced by I } \\
\text { rm and Efficie } \\
\text { uses of } 1954 \\
\text { ary; data are } \\
\text { ol. (6) are fr } \\
\text { inary Hypothes } \\
\text { Labor Market, }\end{array}$ & $\begin{array}{l}\text { ted to } 1958 \text { prices } \\
\text { ector Artesanal en } \\
\text { ol. 1, No. 3, Octobe } \\
\text { f John Todd's correc } \\
\text { ANE's methodology in } \\
\text { acy in Colombian Man } \\
\text { ad } 1967 \text { respectively } \\
\text { not fully comparable } \\
\text { on A. Berry "Unemplo } \\
\text { es and Interpretatio } \\
\text { Bogota, Colombia }\end{array}$ & $\begin{array}{l}\text { d } \\
1969 . \\
\text { ion } \\
\text { the } \\
\text { fac- } \\
\text { In } \\
\text { nent } \\
\text { s" }\end{array}$ \\
\hline
\end{tabular}


Ovet the period 1950-54 to 1964-67, real wages of unskilled workers in construction rose by perhaps $70-75$ percent in Bogota, an average annual increase of $4.2 \%$, with the increase rather concentrated in the period 19581965. (Udall's figures, together with those of Table 2, suggest that the period 1936-1955 was one of no increase, a pattern more extreme than that in manufacturing, and slightly more so than that in agriculture also.)

Data from the 1954 and 1967 commerce censuses suggest that real wages paid by small establishments, rose, in some cases very substantially and perhaps overall about the same as small firms in manufacturing and unskilled construction workers. Real wage changes in these latter two categories (over roughly the same period) were about 20-30 percent (1953-1966) and 50-60 percent (1950 to 1970$)^{1}$ respectively, while in small scale commerce they appear to have been 20-40 percent (1954 to 1967). (See Table 3)

As noted earlier Udall calculated that maids' wages in Bogota took a sharp dip around 1950 with a fairly rapid increase then occurring through about 1967; the increase over 1958-67 was about 50\%, and from 1950-54 to 1964-67 perhaps $60-70 \%{ }^{2}$ Udall's Bogota street sweepers' wages indicate an

etc." and sales people was drawn differently in the two years so the change in composition between these two categories is, unfortunately, uninterpretable. But the relative increase in office workers compared to profiessionals is of interest and does hint that the representative white collar worker may have had a more rapid increase in real income than indicated by the average figure cited. (In 1953 the industrial census indicated--after adjustment for the subsequent dividing line used to define blue and white collar workers--a figure of about 19 thousand white collar workers.)

${ }^{1}$ Over 1954-1967 the increase was greater but wages fell in absolute terms in the succeeding years.

2 Because of small sample and in some respects doubtful methodology, these data are not hard. But they are suggestive. 
increase of $18-21$ percent over $1950-53$ to $1964-66 .^{1}$

As was true for the previous period, little is known about the distribution of capital incomes and how it may have changed during this recent period, nor the relationship between capital incomes and labour incomes. (As discussed in the section below, the share of income ${ }^{2}$ going to physical capital appears to have decreased during the period in question.)

The only piece of evidence possibly throwing some light on distribution of capital incomes is information from the tax returns. Urrutia cites CEPAL's estimate that the $2.9 \%$ of tax payers reporting the highest income had $35.7 \%$ of national income in 1953 ; meanwhile a comparable figure calculated by Urrutia in 1965 indicated that they only accounted for 12.1 to $14.1 \%$ of national income in that year. ${ }^{3}$ It may be assumed that almost all of the individuals in question (natural persons as opposed to juridical persons--although the very high figure of 1953 suggests that there may have been a confusion--were almost all in the non-agricultural sector, since it is well-known that farmers are normally able to almost completely evade taxes.

If such a sharp decrease occurred, this would indicate that the distribution of capital may have been becoming more equal, and certainly that the highest capital incomes represented a smaller share of national

${ }^{1}$ See Urrutia and Arrubla, Compendio..., op. cit., p. 80.

${ }^{2}$ Income related to current production, i.e., excluding capital appreciation.

${ }^{3}$ Urrutia, "Variacion Historica...," 오. it. 
income in the latter year than in the former. But these figures warrant very careful scrutiny before being used. ${ }^{1}$

In any case, pending further checking of the tax figures, they are consistent with the conclusion that the capital share has declined and that income distribution improved. This result holds also, if it be assumed that, within each of twelve occupational categories, ${ }^{2}$ distribution did not change over the period. ${ }^{3}$ The combined effect of the shifting occupational distribution of this labour force and the changes in relative mean incomes among occupations had, in fact, a substantially positive impact within the upper part of the distribution, as shown in Table 8 . The share of the top decile would, under these assumptions, have fallen by from 3 to 7 percent. ${ }^{4}$ Distribution could have worsened only if these were substantial

${ }^{1}$ Comparing 1937 figures from the Contraloria General de la Republica with CEPAL's 1953 figures Urrutia concluded that a concentration at the top had occurred between these two years. But the doubts surrounding the 1953 figures lessen the confidence that can be placed on this conclusion, as does the fact that a higher share of high incomes would be in agriculture in the former year, and would therefore presumably go essentially unreported or reported so far below their true level that they might not enter the figures of the Contraloria.

2 Agricultural wage earners, other agricultural labour force, manufacturing blue collar workers, manufacturing white collar workers, government employees, commerce workers (excludes large capitalists), artisans, construction workers, maids, (technical) professionals, non-technical professionals, and "other labour and capital."

3 The distribution assumed within each category was, for several occupational categories, based on DANE's 1970 household survey, the only source of such information to date. For other sectors CEDE's eight city unemployment survey of 1967 was useful. (CEDE, "Encuestas Urbanas....," ㅇp. cit.)

${ }^{4} \mathrm{~A}$ range is presented since there is uncertainty as to the changes in size of some of the categories used, and hence also in the residual category "other labour and capita1." The two values are designed to provide lower and upper limits with respect to the change over 1951-1964 at a rather high confidence level. (Since the data for both years suffer many weaknesses, the level of confidence with respect to the absolute figures is, of course, not high.) 
worsening of the intra-occupational distribution, a matter on which we have to date no empirical evidence.

After reviewing the evidence on changes in functional distribution we briefly discuss the agricultural sector and try to summarize distribution changes for the economy as a whole.

Functional Distribtuion of Income: Trends Since Cerca 1950

It is easier to construct historical series on functional distribution than on personal or family distribution, and since the two may be expected to bear a rather close relation, this is a useful exercise. The basic distinction usually made is between labour income and capital income-where the former includes all payments (and imputations, if the calculation is a sophisticated one) to labour. Within labour income it is often of interest to distinguish the part accruing to "human capita1". More specifically, three "labour shares" are of particular interest: a) the share of national income paid to people in return for their services (paid labour share); the total labour share, i.e., the paid labour share plus the imputed income of the self employed corresponding to their labour inputs, and c) the pure labour share, i.e., the share of national income corresponding to basic labour services as distinct from the additional income related to services which are based on education and learned skills. Unfortunately the paid labour share is, from a conceptual point of view, the least interesting of the measures but it is the only one for whose calculation data are fairly readily available. That part of income which accrues as a result of holding capital, either physical or human, is the complement of the pure labour share, so in some contexts it is the most interesting labour share. But since certain institutions, such as primary universal education, may imply that the distribution of human wealth is less unequal than that of physical wealth, and, since in any case it 
tends to have different determinants, the total labour share is also of considerable interest, as the complement to the physical capital (including land) share. The paid labour share is of interest primarily in that it constitutes a first step in the measurement of the other two.

As seen in Table 4, the paid labour share of gross domestic product (at factor cost). ranged from about 32 to almost 39 percent over the period 1950-1969 and showed a general upward trend. The share of estimated net domestic product (at factor cost) rose from 34.2 to 42.5 percent. ${ }^{1}$ While there are undoubtedly errors in these figures, they are probably not so serious as to throw into question the clear increase in the paid labour share. Although part of the increase in the paid labour share during this period was associated with increases in specific sectors, in particular manufacturing, transportation and in smaller degree a couple of other sectors, agriculture (the largest single sector) showed a substantial decline so that the net effect of intrasectoral changes in the share was less than one point (i.e., with the 1950 sectoral distribution of value added and 1967 labour shares within each sector, the overall paid labour share (of G.D.P.) would have risen only from 32.0 to 32.7). Most of the increase was associated with the intersectoral shifts, especially towards government, banks, etc., and construction. During the latter part of the period the decrease in the share of agriculture ${ }^{2}$ also contributed,

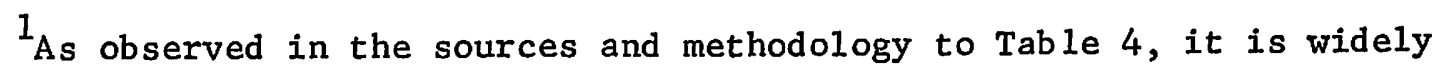
believed that the National Accounts overestimate private sector depreciation, and by an increasing amount over time; this, by itself, would imply that these figures are upward biased (other data being correct) by an increasing amount; on the other hand, no account is taken in the National Accounts of public sector depreciation, which could have been increasing over time.

${ }^{2}$ In agriculture the decline in the labour share is associated with the advent of commercial agriculture whose share in total agricultural production (including livestock) rose from about 7-10 percent in 1950 to about 18-24 percent in 1967, (in 1958 prices) where commercial agriculture is defined as including cotton, rice, sugar, for refining, barley, sorghum, soybeans, sesame, 50 percent of wheat output and 10 percent of the production of corn and potatoes. 


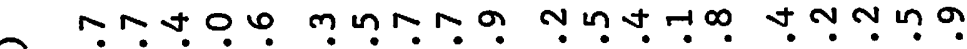
E

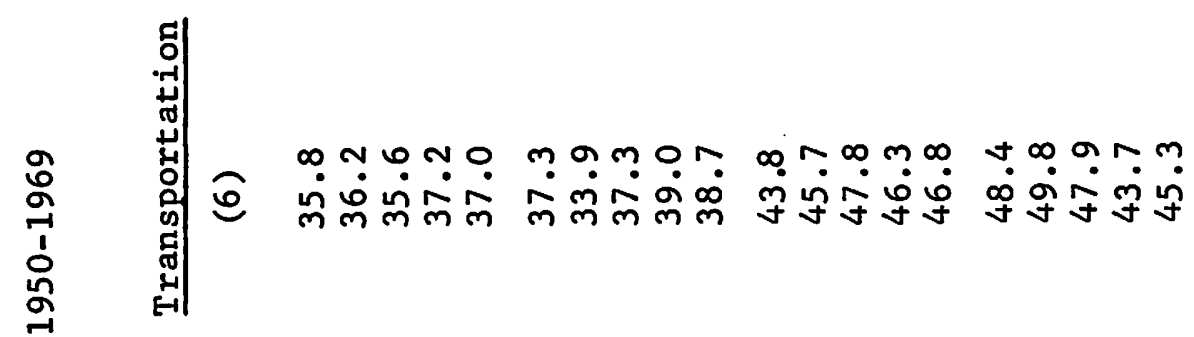

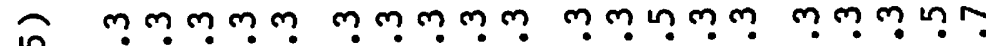

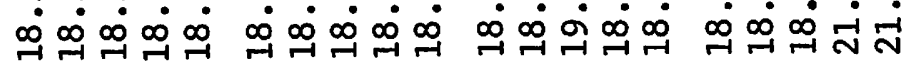

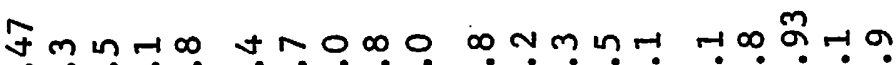

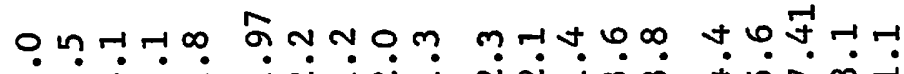



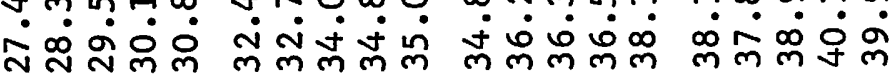
|






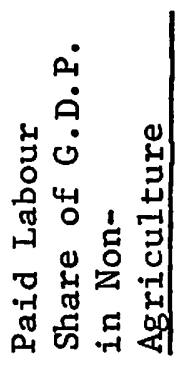

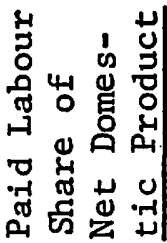

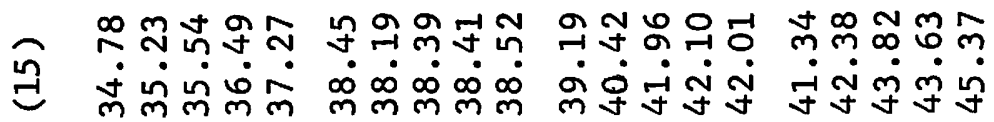



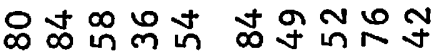

き

0 ก ก ก

NNM 0

ก மํำ

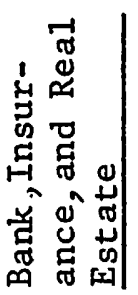

ดัฟก ก

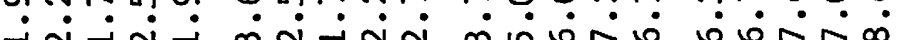


$\underset{\ominus}{\stackrel{0}{\ominus}} \stackrel{0}{\circ}$

$=$

$=$

$=$



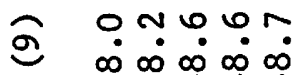

유

r.?

$0.7 \infty \pi, 0$

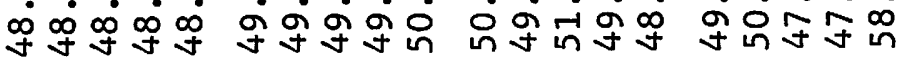

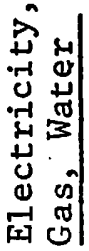

ㄴ

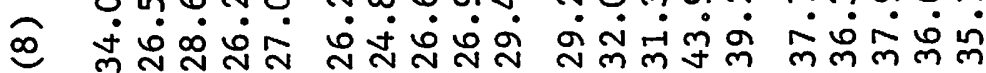


Sources and Methodology - Table 4

For all sectors with the exception of agriculture the figures represent the national accounts datum "payments of labour" related to gross domestic product at factor cost, with all figures in current pesos. The labour payment figure includes salaries, bonuses, commissions, and other forms of income in money or specie calculated before the deduction of personal charges for social security. Payments to people habitually residing in other countries are excluded while those received by nationals but paid by other countries are included. Employer contributions to social security are included. There is no imputation for the labour income of self-employed. (See Banco de la Republica Cuentas Nationales 1950-1967, p. 7.)

The national accounts figures appear to be reasonable for most of the sectors, though estimates are particularly difficult to effect in agriculture and some of the smaller sectors. The author's estimate in an independent study of wage shares in agriculture indicated a paid labour share of 23 percent in 1960 as opposed to the 31.8 percent given in the national accounts. Both estimates have substantial elements of the arbitrary in them, in particular estimates on days worked per year, etc., and they are only partially independent of each other. The difference, however, lies in the fact that the national accounts estimate of the total paid labour force in agriculture is higher than my own, due to their including all workers classified in the population censuses as working for someone else plus a portion (one-half) of the independent workers. While it is indeed true that many independent workers also earn income as labourers, it seems clear on the other hand that some of the population classified in the census as workers hold small farms from which a part of their income accrues; they are not full time workers. I assumed that these two effects offset each other. The Banco estimate of the paid labour share for this sector was thus decreased in each year by the coefficient .725 (the ratio of my estimate to theirs in 1960). Since occupational structure has changed little over the period in question, it seemed fairly safe to apply the same coefficient for all years.

An independent estimate of the manufacturing paid labour share of gross value added differs somewhat (on the lower side) from the national accounts figures presented here. My figure for 1960 was 31.4 instead of the national accounts 34.9; for 1967 mine was 34.0 instead of 38.9. In commerce, the national accounts left unchanged up to 1968 the 18.3 percent estimate coming from the 1954 commerce census; the 1967 census suggested a figure of 21.7 percent; its coverage, however, appeared to be less complete than that of 1954 , which might suggest a relative upward bias in 1967, since the establishments missed were almost certainly disproportionately small sized ones. Any increase presumably occurred gradually over the years. This problem is relatively unimportant in the estimation of the total paid labour share. In other sectors it is very difficult to execute independent checks. In construction it is possible that value added is underestimated and the labour share overestimated, but it is not clear whether by an increasing or decreasing amount. Overall it appears that the national accounts estimates are well within the ballpark after the adjustment made in 
Sources and Methodology for Table 4 (continued)

agriculture; it would, for example, be very surprising if the figures were in error by more than 5 percent in the overall paid labour share figure. For purposes of comparison, Col. (13) presents the result of accepting the national accounts remuneration figure for agriculture; Col. (12) uses the author's estimates, i.e., it is consistent with all of the sectoral figures presented.

Somewhat greater doubt attaches to the estimates of labour share of net domestic product since the depreciation figures appear dubious; in the private sector they are probably biased up, but no calculation is made for public capital like roads, so the net bias is unclear. The private sector upward bias may well have increased over time (as a share of G.D.P.), but so may the public sector downward bias. A guess would be that there has been a net increase in an upward bias over time, but this result is too speculative to make it worthwhile incorporating into the calculations.

Col. (15) presents the paid labour share of G.D.P. in non-agriculture. 
since by that time its labour share was well below the overall average. The increased share of commerce worked in the opposite direction. The paid labour share for non-agriculture as a whole rose very substantially from just under 35 percent to about 45 percent.

The increase registered in the paid labour share for the period 1950-1969 of over 6.5 percent of gross domestic product may imply that the total labour share moved in the same direction, but this cannot be assumed without further analysis. The increased number of large size firms and the gradual decrease in the relative importance of the family unit and of the unpaid worker (be he manager or family helper) tends, in some economies, to raise the paid labour share over time when the total labour share is not increasing; the former phenomenon (an increasing share of the labour force working for pay) does appear to have been occurring in Colombia-the share of paid workers rose from 55.4 percent in 1951 to about 58 percent in 1964 and about 60 percent in $1970^{1}$ (see Table 5)--but there is no decrease in the total labour share of private sector income--instead, as indicated in Table 6 , there is a 3-4 percent shift in the other direction (predictably less than the increase in the paid labour share). As observed in Table $6 \mathrm{~b}$, the increase in the total iabour share is sma11 (less than 2, percent) when related to gross national income; given the uncertainty

${ }^{1}$ The 1970 figure may be somewhat overestimated since the Encuesta de Hogares appears to have underestimated the relative size of the agricultural labour force, where paid workers are a lower share of the total than in non-agriculture. On the other hand, of three alternative estimates available, two put the figure above 60 percent. So, although it might be as low as 59 percent, 60 percent is perhaps a best estimate.

Over the same years the share of the male population found in the categories "employers, independent workers, and family helpers" fell from 47.5 percent in 1951 to 45.5 in 1964 to $40-41$ percent in 1970 ; in the nonagricultural sector the decline was from 31.97 in 1951 to 30.00 in 1964; a 1970 calculation is not yet available. 


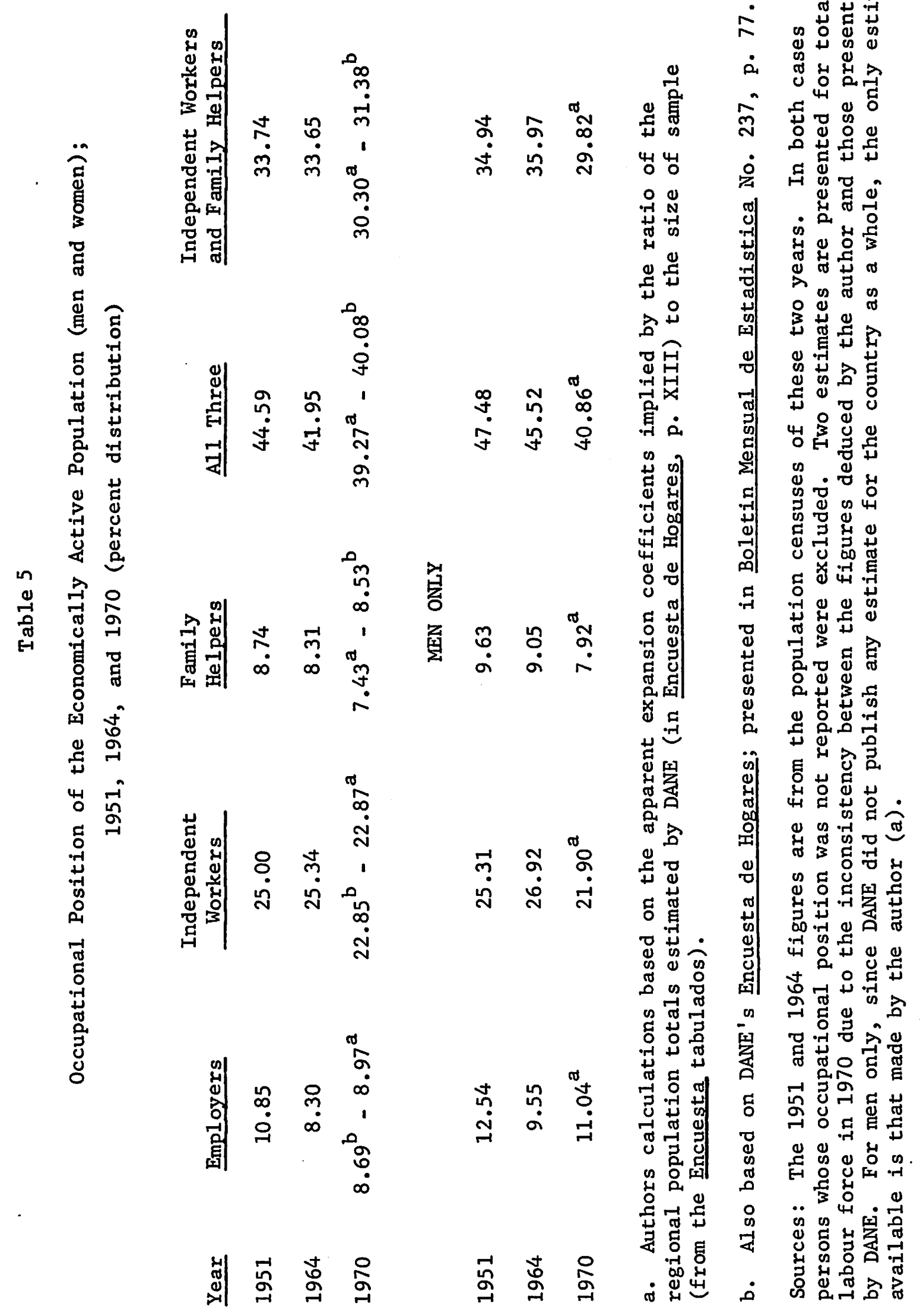


Table $6 a$

Labour Share and Capital Shares of Net National Income at Factor Cost

\begin{tabular}{|c|c|c|c|c|c|c|c|c|}
\hline Year & $\begin{array}{l}\text { Paid } \\
\text { Labour }\end{array}$ & $\begin{array}{l}\text { Imputed } \\
\text { Labour }\end{array}$ & $\begin{array}{l}\text { Total } \\
\text { Labour }\end{array}$ & $\begin{array}{l}\text { Capital In- } \\
\text { come of } \\
\text { Persons \& Un- } \\
\text { incorporated } \\
\text { Enterprises }\end{array}$ & $\begin{array}{l}\text { Business } \\
\text { Savings \& } \\
\text { Direct Taxes } \\
\text { of Incorpor- } \\
\text { ated Entities }\end{array}$ & $\begin{array}{l}\text { Private } \\
\text { Sector } \\
\text { Capital } \\
\text { Income } \\
\end{array}$ & $\begin{array}{l}\text { Public } \\
\text { Sector } \\
\text { Capital } \\
\text { Income } 1 \\
\end{array}$ & $\begin{array}{c}\text { Total } \\
\text { Capital } \\
\end{array}$ \\
\hline & (1) & (2) & (3) & (4) & (5) & $\begin{array}{c}(6)= \\
(4)+(5)\end{array}$ & (7) & (8) \\
\hline $\begin{array}{l}1950 \\
1951 \\
1952 \\
1953 \\
1954\end{array}$ & $\begin{array}{l}34.57 \\
35.12 \\
34.55 \\
35.37 \\
34.53\end{array}$ & $\begin{array}{l}28.76 \\
28.20 \\
28.76 \\
28.38 \\
28.82\end{array}$ & $\begin{array}{l}63.33 \\
63.32 \\
63.31 \\
63.75 \\
63.35\end{array}$ & $\begin{array}{l}33.06 \\
32.56 \\
32.80 \\
32.37 \\
32.60\end{array}$ & $\begin{array}{l}3.21 \\
3.33 \\
3.15 \\
2.99 \\
3.35\end{array}$ & $\begin{array}{l}36.27 \\
35.89 \\
35.95 \\
35.36 \\
35.95\end{array}$ & $\begin{array}{r}0.40 \\
.79 \\
.74 \\
.89 \\
.70\end{array}$ & $\begin{array}{l}36.67 \\
36.68 \\
36.69 \\
36.25 \\
36.65\end{array}$ \\
\hline $\begin{array}{l}1955 \\
1956 \\
1957 \\
1958 \\
1959\end{array}$ & $\begin{array}{l}36.62 \\
35.44 \\
35.67 \\
37.78 \\
37.55\end{array}$ & $\begin{array}{l}27.57 \\
28.33 \\
28.10 \\
26.53 \\
26.37\end{array}$ & $\begin{array}{l}64.19 \\
63.77 \\
63.77 \\
64.31 \\
63.92\end{array}$ & $\begin{array}{l}31.41 \\
31.85 \\
31.48 \\
29.45 \\
29.71\end{array}$ & $\begin{array}{l}3.63 \\
3.66 \\
4.06 \\
4.81 \\
5.44\end{array}$ & $\begin{array}{l}35.04 \\
35.51 \\
35.54 \\
34.26 \\
35.15\end{array}$ & $\begin{array}{l}.77 \\
.72 \\
.69 \\
.82 \\
.93\end{array}$ & $\begin{array}{l}35.81 \\
36.23 \\
36.23 \\
35.08 \\
36.08\end{array}$ \\
\hline $\begin{array}{l}1960 \\
1961 \\
1962 \\
1963 \\
1964\end{array}$ & $\begin{array}{l}38.32 \\
39.44 \\
41.28 \\
42.28 \\
40.24\end{array}$ & $\begin{array}{l}25.81 \\
25.57 \\
25.03 \\
24.20 \\
25.76\end{array}$ & $\begin{array}{l}64.13 \\
65.01 \\
66.31 \\
66.48 \\
66.00\end{array}$ & $\begin{array}{l}29.12 \\
28.82 \\
28.22 \\
27.51 \\
28.13\end{array}$ & $\begin{array}{l}5.94 \\
5.20 \\
4.75 \\
5.63 \\
5.73\end{array}$ & $\begin{array}{l}35.06 \\
34.02 \\
32.97 \\
33.14 \\
33.86\end{array}$ & $\begin{array}{l}.81 \\
.97 \\
.72 \\
.38 \\
.14\end{array}$ & $\begin{array}{l}35.87 \\
34.99 \\
33.69 \\
33.52 \\
34.00\end{array}$ \\
\hline $\begin{array}{l}1965 \\
1966 \\
1967 \\
1968 \\
1969\end{array}$ & $\begin{array}{l}40.54 \\
41.32 \\
42.41 \\
41.79 \\
43.68\end{array}$ & $\begin{array}{l}25.09 \\
24.65 \\
24.42 \\
24.57 \\
23.36\end{array}$ & $\begin{array}{l}65.63 \\
65.97 \\
66.83 \\
66.36 \\
67.04\end{array}$ & $\begin{array}{l}28.28 \\
27.65 \\
27.43 \\
27.35 \\
26.17\end{array}$ & $\begin{array}{l}5.73 \\
5.90 \\
5.57 \\
5.70 \\
6.28\end{array}$ & $\begin{array}{l}34.01 \\
33.55 \\
33.00 \\
33.05 \\
32.45\end{array}$ & $\begin{array}{l}.36 \\
.48 \\
.17 \\
.59 \\
.24\end{array}$ & $\begin{array}{l}34.37 \\
34.03 \\
33.17 \\
33.64 \\
32.69\end{array}$ \\
\hline
\end{tabular}

Source: Cuentas Nacionales for the paid labour estimates, except for agriculture. (See the discussion with Table 4). Imputed labour income was estimated as follows. The share of labour force in each of the categories employers, independent workers, white collar workers and blue collar workers was calculated for 1951, 1964, and 1970 based on population census and sample information and was interpolated for the intervening years. (See A. Berry, "Some Determinants...," op.cit., Table 4). Relative remunerations for the four categories were based on DANE's 1970 Encuesta de Hogares and CEDE, Encuestas de Empleo y Desempleo, Annexo Estadistico. These two sources were not fully consistent and more faith was placed in the latter. The same relative income ratios were assumed to hold for the whole period. It was assumed for employers and independent workers that 50 percent of their income was due to their labour input. (See A. Berry, "Some Determinants...," op.cit., Table 6).

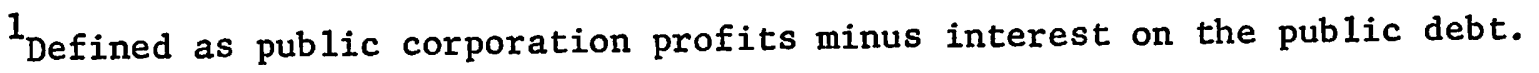


Table 6b

Labour and Capital Shares of Gross National Income at Factor Cost

\begin{tabular}{|c|c|c|c|c|c|c|}
\hline Year & $\begin{array}{l}\text { Tota1 } \\
\text { Labour } \\
\text { Share } \\
\end{array}$ & $\begin{array}{l}\text { Capital In- } \\
\text { come of } \\
\text { Persons \& Un- } \\
\text { incorporated } \\
\text { Enterprises } \\
\end{array}$ & $\begin{array}{l}\text { Business } \\
\text { Savings \& } \\
\text { Direct Taxes } \\
\text { on Incorpor- } \\
\text { ated Entities }\end{array}$ & $\begin{array}{l}\text { Private } \\
\text { Sector } \\
\text { Capital } \\
\text { Income }\end{array}$ & $\begin{array}{l}\text { Public } \\
\text { Sector } \\
\text { Capital } \\
\text { Income } \\
\end{array}$ & \begin{tabular}{c}
\multicolumn{2}{c}{ Total } \\
Capital Share
\end{tabular} \\
\hline & (1) & (2) & (3) & (4) & (5) & (6) \\
\hline $\begin{array}{l}1950 \\
1951 \\
1952 \\
1953 \\
1954\end{array}$ & $\begin{array}{l}59.18 \\
58.80 \\
58.72 \\
59.20 \\
59.06\end{array}$ & $\begin{array}{l}37.45 \\
37.38 \\
37.67 \\
37.19 \\
37.17\end{array}$ & $\begin{array}{l}3.00 \\
3.09 \\
2.92 \\
2.78 \\
3.12\end{array}$ & $\begin{array}{l}40.45 \\
40.47 \\
40.59 \\
39.97 \\
40.29\end{array}$ & $\begin{array}{l}.37 \\
.73 \\
.69 \\
.83 \\
.65\end{array}$ & $\begin{array}{l}40.82 \\
41.20 \\
41.28 \\
40.80 \\
40.94\end{array}$ \\
\hline $\begin{array}{l}1955 \\
1956 \\
1957 \\
1958 \\
1959\end{array}$ & $\begin{array}{l}59.38 \\
58.85 \\
57.46 \\
56.03 \\
56.47\end{array}$ & $\begin{array}{l}36.55 \\
37.10 \\
38.26 \\
39.07 \\
38.50\end{array}$ & $\begin{array}{l}3.36 \\
3.38 \\
3.66 \\
4.10 \\
4.81\end{array}$ & $\begin{array}{l}39.91 \\
40.48 \\
41.92 \\
43.26 \\
43.31\end{array}$ & $\begin{array}{l}.71 \\
.66 \\
.62 \\
.71 \\
.82\end{array}$ & $\begin{array}{l}40.62 \\
41.14 \\
42.54 \\
43.97 \\
43.53\end{array}$ \\
\hline $\begin{array}{l}1960 \\
1961 \\
1962 \\
1963 \\
1964\end{array}$ & $\begin{array}{l}57.23 \\
58.56 \\
59.81 \\
59.78 \\
60.28\end{array}$ & $\begin{array}{l}36.65 \\
35.89 \\
35.26 \\
34.82 \\
34.36\end{array}$ & $\begin{array}{l}5.30 \\
4.68 \\
4.28 \\
5.06 \\
5.23\end{array}$ & $\begin{array}{l}41.95 \\
40.57 \\
39.54 \\
39.88 \\
39.59\end{array}$ & $\begin{array}{l}.72 \\
.87 \\
.65 \\
.34 \\
.13\end{array}$ & $\begin{array}{l}42.77 \\
41.44 \\
40.19 \\
40.22 \\
39.72\end{array}$ \\
\hline $\begin{array}{l}1965 \\
1966 \\
1967 \\
1968 \\
1969\end{array}$ & $\begin{array}{l}59.77 \\
59.74 \\
60.53 \\
60.19 \\
60.94\end{array}$ & $\begin{array}{l}34.68 \\
34.49 \\
34.27 \\
34.11 \\
33.13\end{array}$ & $\begin{array}{l}5.22 \\
5.34 \\
5.05 \\
5.17 \\
5.71\end{array}$ & $\begin{array}{l}39.90 \\
39.83 \\
39.32 \\
39.28 \\
38.84\end{array}$ & $\begin{array}{r}.33 \\
.43 \\
.15 \\
.53 \\
.22\end{array}$ & $\begin{array}{l}40.23 \\
40.26 \\
39.17 \\
39.81 \\
39.06\end{array}$ \\
\hline
\end{tabular}

Sources and Methodology: Same as for Table $6 a$. 
surrounding the depreciation figures, one cannot say conclusively than an increase has occurred; obviously the opposite cannot be said either. In either case it appears that the occupational position shift is responsible for much of the increase in the paid labour share. If the average imputed wage income of people not receiving a paid wage is equal to that of those who are (an assumption not much different from that implicit in the figures of Table 6), a shift of 4.5 percent of the labour force from the unpaid category to the paid would (assuming also that the group which shifts receives an average level of wages) increase the paid wage share by 4.5 percent of total income. It would thus account for the bulk of the actually observed increase of 6-8 percent (depending on whether gross or net domestic product is the base). In fact the assumption that the imputed wage of the "group which shifts" ${ }^{1}$ be equal to the average wage of paid people is probably upward biased since this group involves in large measure farmers. At the same time it is true that the paid workers/1abour force ratio rose more rapidly for men than in total; since men have higher wages and earnings than women, this factor would work in the opposite direction. Even on the conservative assumption that their average income was one-half that of other paid workers, this factor would still account for one-quarter to one-third of the observed increase; at the other extreme (if the G.D.P. figures are the more relevant base) this shift could account for 75 percent or more of the increase. But though it is conceivable that little increase occurred in the total labour share, it seems very unlikely that this could have been the case in the non-agricultural sector; the national accounts figures indicate an increase of the paid labour share between 1950 and 1969 of about

In fact, of course, it is possible that most of the change in the share of people who are paid occurs via retirements and entries to the labour force, and not by actual shifting. 
35 to 45 percent; the share of non-agricultural workers receiving remuneration rose from about 68 percent to perhaps 71 percent $^{1}$ over this period, so unless the marginal group of independent workers in 1951 who in fact had "switched" to employee status by 1964 were high in the income distribution, this switch could not be the sole factor.

How has the distribution of total labour income between "pure" labour and human capital changed over time? Unfortunately, estimating the pure labour share is difficult--even in conceptual terms--in an economy with such prevalence of imperfect labour markets as Colombia's. The concept is perhaps more meaningful in agriculture, where a substantial portion of theflabour force may have relatively little "human capital" but the exercise is still worthwhile for the economy as a whole. One might guess, crudely, that in the period 1950-1969 the pure labour share in the system (according to precisely how one defines it and depending also on uncertainties in statistical information) ${ }^{2}$ fell by about 7-9 percent. Perhaps the most interesting series--(col. 1 of Table 7$)$, i.e., where the pure wage rate is assumed to

$1_{\text {The figure was }} 70$ percent in 1964; no estimate is yet available for 1970 so the change of the previous period was extrapolated.

2 As explained in the methodology of Table 7, the key wage series used here are those of agricultural workers and unskilled construction workers. As observed in Table 2 these two series bear a rather close relation to each other over time, and thus lend some mutual support to the relevance of each in measuring the (more or less) equilibrium wage of groups with little human capital. It might be argued that since the two wage rates are not identical that either a) construction workers have more human capital than agricultural workers in which case we have upward. biased changes in the pure labour share over time, or b) that a labour market imperfection associated with imperfect labour mobility accounts for the differential--in which case the interpretation of the pure labour share becomes cloudier. These refinements cannot be handled without more information; of course there are other interpretations of the differential, e.g., cost of living differences. 
Table 7

Factor Shares of Net Domestic Income: $1950-1969^{1}$

Pure Labour Share Capital Share

Labour

$\begin{array}{cc}\text { Paid } \\ \text { Capital } & \text { Labour } \\ \text { Share } & \text { Share }\end{array}$

$\begin{array}{ccc}\text { Year } & \frac{\text { Est. A }}{(1)} & \frac{\text { Est. B }}{(2)} \\ & & \\ 1945 & 38.2 & \approx 42.05^{\mathrm{a}} \\ 1946 & 36.7 & \\ 1947 & 38.4 & \\ 1948 & 40.4 & \\ 1949 & 34.7 & \end{array}$

Est. A Est. B

Share

$\frac{\text { Share }}{(6)}$

(7)

Agriculture Non-agriculture

(8)

(9)

34.87

36.8

195234.4

$1953 \quad 32.8$

34.53

33.11

26.68

27.81

62.68

37.32

34.20

47.85

34.69

28.32

29.61

62.72

37.45

31.36

30.37

31.81

$62.72 \quad 37.28$

34.23

47.77

43.68

$35.05 \quad 41.91$

36.83

34.29

38.49

31.6

29.90

31.30

33.00

62.90

36.10

36.39

42.38

32.63

33.13

32.27

63.79

31.13

63.33

36.21

36.67

29.2

31.69

33.65

28.90

62.82

37.18

35.19

42.38
37.92

$35.14 \quad 34.10$

36.38

$36.97 \quad 36.88$

37.99

37.80

37.99
39.50

$\begin{array}{llll}33.46 & 29.52 & 63.26 & 36.74\end{array}$

$\begin{array}{llll}33.92 & 29.31 & 64.02 & 35.98\end{array}$

$\begin{array}{llll}35.18 & 30.24 & 65.18 & 34.82\end{array}$

$\begin{array}{llll}34.63 & 29.91 & 65.03 & 34.97\end{array}$

38.84

40.58

41.34

44.03

$39.54 \quad 39.34$

39.34

39.84

$34.29 \quad 27.59$

64.8635 .14

40.49

40.14

$41.52 \quad 38.75$

$\begin{array}{llll}34.54 & 29.28 & 64.64 & 35.36 \\ 36.52 & 31.21 & 65.42 & 34.58\end{array}$

34.21

36.52

31.21

$27.2 \quad 32.26$

37.49

32.45

64.71

31.47

33.63

$\begin{array}{ll}65.10 & 34.90\end{array}$

40.76

42.42

35.81

36.90

24.52

24.75

23.28

22.71

23.38

28.67

28.49

30.48

31.29

1970


domestic product (income) over time, according to the national accounts estimates; if that decrease has in reality not occurred, the total labour share would have risen less than indicated here, or possibly not at all (see Table 4).

This is a rough estimate based on an interpolated figure for the unskilled construction wage in 1945. (See the methodology of Estimate B below.)

Sources and Methodology:

Estimate $A$ is based on the assumption that pure labour income corresponded to the male agricultural wage, and that the days worked per year vere 250 for everyone. This procedure has at least one upward biasing feature, the assumption that the male wage be applied to women and children (who have lower wages) and to family helpers (who probably work on average considerably less than 250 days). A downward biasing feature is the assumption of 250 days worked for everyone; the average in urban areas is higher.

For Estimate $B$ the above assumptions were applied only with respect to the agricultural labour force while the wage series for unskilled construction workers (see Table 2) was applied to non-agricultural labour force, with the assumption of 275 days worked. Col. (5), total labour share, is based on the summation of the paid labour income (Table 4) and imputed labour labour shere of total income of unpaid workers (employers and own-account workers). Col. (7), presented for purposes of comparison, is from Table 4.

For Col. (8) it was assumed that net domestic income in agriculture was .95 times gross value added, and (different from Col. (1)) an adjustment was made (multiplication by the coefficient 0.92 ) to take account of the fact that unpaid family helpers work less than other members of the labour force and that women and children earn lower incomes (and hence presumably have lower inputs).

Col. (9) used the assumptions of Col. (2), applied to the non-agricultural sector. 
correspond to that of the agricultural male (over 18 years)--indicates a decrease from 36 percent in 1950 to 28 percent in 1969. (Splicing the earlier national accounts series onto the one used here permits the calculation of the ratio for 1945-50, during which period, although fluctuating erratically, ${ }^{2}$ it appears to have fallen a little. While there is substantial margin of error in these figures, ${ }^{3}$ a gradual downward trend from something around 40 percent in the late 40 's to something probably now well under 30 percent is hardly mistakable. It is of interest to note that the periods of rapid decline in this share have been, not surprisingly, those in which income per capita has grown most rapidly, i.e., 1945-1956 and 1967-1969. Meanwhile the human capital share has risen considerably as an increasing share of the population attains each level of education. This increase is concentrated in the two periods of rapid decrease in the pure labour share, although it continued to ease up during the slow growth period, 1957-1966. Though there are suggestions of a decrease in the rate of return to certain types of human capital over time

i

Bogota street sweepers and other individuals occupied in jobs where minimum wage legislation can play a role cannot be used as a measure of the equilibrium pure labour wage, even though it is, of course, relevant that groups of people with no human capital may receive above equilibrium wage levels because of monopoly power or social legislation.

2 Probably due in part to the lower quality of the data in this period. 3

${ }^{3}$ Note that there is some difficulty in the use of national accounts income figures together with my independent estimates of employed population, which are generally greater than those used in the national accounts estimates. Since some components of the national accounts are based on average income times number of people, such estimates would have been higher had the higher population figures been used. This means that the figures presented here may overestimate the labour share at all points in time, assuming the national accounts use correct average income figures in all cases. The error implicit is not likely to be great and the change in the bias over time even less. 
(e.g., the decreasing ratio of white collar/blue collar wages in industry) this factor, if present, has been outweighed by the other. ${ }^{1}$ The total physical capital share (i.e., the complement of the total labour share) declined from about 37 percent in 1950 to about 35 percent in 1969; the share of net domestic product reaching the hands of individuals fe11 by about 5 percent as business savings and direct taxes on corporations rose (see Table 6). Sectoral trends of the pure labour share are generally similar to those of the paid labour share. In agriculture the pure labour share, according to an estimate presented in a separate study, ${ }^{2}$ was within the range 30 percent to 36 percent in 1960, having fallen from somewhere in the range 43-50 in 1950. As of 1969 the range appeared to be about the same as in 1960 or a shade lower. In manufacturing one could argue that a minimum estimate of the return to human capital (i.e., the part not going to "pure labour") would be the differential between the average earnings of workers in the larger firms and those in the smaller firms--the difference would be due either to human capital or to monopoly power of the labourers. Such a calculation would indicate that, as of 1964, this share was bout 30 percent in factory manufacturing, i.e., about two-thirds of total labour income. ${ }^{3}$

$1_{\text {The total labour share may be decomposed alternatively into the pure }}$ labour share, the primary education share, the secondary education share and the university share; this alternative way of viewing changes over time may be of interest in terms of educational and other policies.

${ }^{2}$ See Albert Berry, "Land Distribution, Income Distribution and the Productive Efficiency of Colombian Agriculture," Growth Center Discussion Paper No. 108, 1971.

3 The average wage rate in 1964 was about 12.2 thousand pesos whereas the wage rate of the smallest size group was only about 4 thousand. Note that a good deal of this human capital share goes to white collar workers. The paid labour share of gross value added in 1964 was 38.1 (see Table 4). This would be higher (say 42 percent) in the factory subsector. As a share of net value added, it would be say 46 percent. Inclusion of unpaid workers' labour income could raise it to 47 percent. Two-thirds of this is a little over 30 percent. 
The evidence on changes in functional distribution tend to reinforce that from earnings series with respect to the period in question--the early fifties to the mid-sixties. In agriculture, both a declining paid labour share, and a wage rate rising less rapidly than average income suggest that income distribution probably worsened again during the period, although it seems unlikely that the shift was as rapid as in the previous one. The decrease in the paid labour share occurring between 1950-54 and 1954-67 (see Table 4, col. 1) was concentrated in the latter part of the 50's, since which time a levelling off occurred. The pure labour share followed essentially the same pattern (see Table 7) lending more support to the conclusion that during a good part of the period under discussion distribution was not worsening notably, unless that of capital income was. But agriculture may well be a sector where this last phenomenon was occurring, since the rapid advance of commercial agriculture characterized especially the late $50^{\prime}$ 's and early $60^{\prime}$ s. $^{1}$ Still, if there was an overall worsening throughout the period it seems probable that during some subperiods it was sma11 and that for the period as a whole it was less than in the previous period.

Trying to judge how overall distribution moved involves putting the results for the agricultural and non-agricultural sectors together, and allowing for the fact that the relative importance of agriculture in output and employment was diminishing. Table 8 indicates that, if no intraoccupation changes of distribution occurred, then some improvement occurred in the top forty or fifty percent of the distribution. The top decile

\footnotetext{
${ }^{1}$ See A. Berry, The Development,..., op. cit., Chapter 2.
} 
Table 8

Income Distribution Comparisons,

$1934-6,1951$ and 1964

$1934-6$

1951

1964

Non-Agriculture:

Gini Coefficient

Share of Top $5 \%$

$10 \%$

$20 \%$

$30 \%$

$50 \%$

$.599-.644$

.601

$35.21-38.80$

31.71

47.44-51.95

44.63

62.67-67.01

60.36

$73.30-77.07$

70.66

88.05-90.55

84.66

Bottom

$20 \%$

$1.15-1.56$

n.a. ${ }^{a}$

\section{A11 Sectors:}

$\begin{array}{lrrrr}\text { Gini Coefficient } & .553 & .602-.633 & .57 \\ \text { Share of Top } \quad 5 \% & 38.41 & 40.00-42.22 & 35.66 \\ & 10 \% & 48.16 & 51.15-53.90 & 47.87 \\ & 20 \% & 60.79 & 64.95-67.68 & 63.10 \\ & 30 \% & 70.14 & 74.29-77.01 & 73.73 \\ & 50 \% & 83.79 & 86.14-88.00 & 86.84 \\ \text { Bottom } & 20 \% & 3.78 & 2.49-3.00 & 3.30\end{array}$

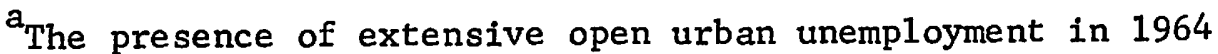
and lack of information as to the income of the unemployed makes it especially hazardous to estimate this value. 
Sources and Methodology:

The 1964 distributions are basically those of Urrutia and Sandoval ("La Distribucion de Ingresos..." op.cit) with a few minor alterations to take account of more recent information. The 1951 distributions on which these figures are based have been estimated using figures on employment by occupational category in 1951 (basically from the population census of that year), estimates of increase in mean income by occupation(based on the sources cited in Tables 1, 2 and 3 ), and the assumption that intra-occupational category distribution did not change between 1951 and 1964. Alternative assumptions were made with respect to some of the mean income changes based on shakier data and some of the employment estimates which were also not firm.

The 1934-6 distribution was based on the same methodology as just described for 1951, except for the wider categories used (only three): agricultural paid workers, the rest of the agricultural labour force, and the non-agricultural labour force. It was assumed that no changes in distribution occurred within any of these broad groupings. The 1934-6 distribution is thus weaker than the later ones both for this reason and because the income data are becoming weaker. In particular, estimates of wage income in agriculture (directly from wage data) and estimates of total agricultural income (see Table 1) are to all intents and purposes inconsistent, the implicit non-wage income being too low. It was accordingly assumed that the non-wage income was higher than is implicit in the figures of Table 1 (specifically, per person); the lower of the two alternative wage rates shown in Table 1 was used. This adjustment had the effect of damping the distribution worsening which still emerges from a comparison of the 1938 and 1951 figures. With this worsening as a sort of null hypothesis, the available figures were adjusted in a direction which made its acceptance less likely. It is my impression that the data weaknesses are not so great as to overturn the result that distribution worsened. Very possibly worsening occurred within the three categories which were distinguished in 1934-6; this would mean that distribution in 1934-6 was less unequal than estimated (all else assumed to be accurate). 
share decreased by $3-6 \%$; the top fifty percent may not have suffered any decrease. And there may have been some small increase in the share of the bottom 20 percent, although this is extremely tentative since the data is particularly weak in the bottom deciles of the distribution. The calculated GINI coefficient fell from .60-.63 to .57 .

Over 1934-6 to 1964 as a whole, Table 8 suggests some decrease in the income of the top decile, definite gains for the next two deciles, no change for the next two, and some decrease for the bottom $50 \%$ as a whole, and for the bottom $20 \%$ as well. The relative worsening of these latter two groups appears to have characterized only the first of the two sub-periods. The only group whose share moved in the same way (up) in both sub-periods was deciles 2 and 3 . The Gini coefficient increased from .55 to .57 .

Though the temptation to draw too much out of the still shaky data base used here must be resisted, the consistency of much of the pattern shown here with Kuznets "worsening, then improving" hypothesis on income distribution in the development process is noteworthy. ${ }^{1}$ The shift from agriculture to non-agriculture has played a role in the apparent 1951-1964 improvement. Assuming such an improvement did really occur, one might be tempted,optimistically, to assume that Colombia had "turned the income distribution corner" and could anticipate a continuation of the positive trend. Certainly such a conclusion is not yet warranted, but the pessimistic opposite is even less warranted。

${ }^{1}$ Simon Kuznets, "Economic Growth and Income Inequality," American Economic Review, Vo1. XLV, No. 1, March, 1955. 
The Problem of Income From Asset Appreciation

Perhaps the major doubt with respect to the conclusions reached to date, and especially with respect to the judgment that distribution may have improved over the second period considered, is the failure to take account of changes in the value of capital assets.

For a full appreciation of changes in income shares of factors, one should treat capital appreciation as a form of income; usually its effects are not allowed for unless there is some marketability of the capital and are therefore not treated in the case of human capital. The ratio of appreciation of physical capital to other forms of income in the period in question has probably been in the range of 10-20 percent in Colombia. ${ }^{1}$ But no studies permitting one to assign this income by classes are yet available, so any judgment as to whether its omission creates a bias or not must be impressionistic.

Certainly the logical hypothesis is that income from asset appreciation is quite concentrated, but since the overall distribution is also quite concentrated it is not a foregone conclusion that it is measurably worsened by taking the appreciation into account. It does seem 1ikely that the distribution of income from capital is more skewed than overall income distribution, and that the distribution of income from asset appreciation is similar to the distribution of wealth, possibly even more skewed since it seems likely that only large-scale capitalists are able to take

${ }^{1}$ A crude estimate by the author suggests a ratio of tangible wealth held by individuals to national income of about 4:1 in 1956. It seems probable that the real appreciation of these assets falls in the range 2-5 percent. This would imply an "appreciation income" equal to 8-29 percent of the regular "national accounts" income. The roughly half of the capital which corresponds to urban land and real estate (including houses) probably appreciates at close to the upper margin of the range set but some other assets may not tend to appreciate at a11. (Appreciation of financial assets appear quite limited.) 
advantage of situations of rapid capital appreciation. The tentative judgment that being able to take account of appreciation would make the distribution somewhat worse is about as far as one can get, however, without further statistics being available. ${ }^{1}$

III Mid-60's to the Present

Tentative information for the late 1960 's suggests that distribution may have worsened again during this period; if so, one hypothesis would follow rather obviously from the historical sequence--that distribution tends to worsen when growth is fast and improve when growth, at least growth of income, is slow. The first period designated above, including rapid growth over 1945 - early fifties and fairly successful growth even in the 1935-45 decade, was one of distribution worsening. The period of the early 50's to the mid-60's included the long stagnation of 1954-1963 and average income per capita did not rise dramatically for the period as a whole--only $1.1 \%{ }^{2}$ The period 1966-70 constitutes a new rapid growth phase in the Colombian economy, and, unfortunately, most of the evidence points

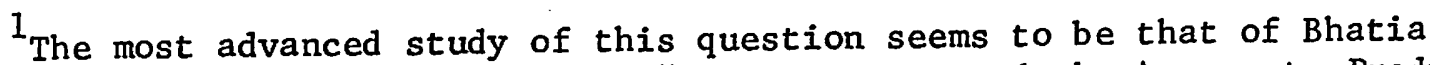
for the United States (See Kul Bhatia, "Capital Gains and the Aggregate Production Function," American Economic Review, Vol. LXII, No. 5, December 1972.). He found that, over 1947-64, accrued capital gains of individuals amounted to $10.66 \%$ of total reported personal income plus accrued capital gains (p. 869). In 1964 the top 5 percent of income recipients appear to have had about 50 percent of all accrued gains, and the bottom 60 percent less than 20 percent of such gains. The top 5 percent of earners would thus receive about 21.5 percent of "income plus accrued capital gains" as opposed to about 16 percent of regular income. Since 1964 was a year of above average accrued capital gains, the more typical increase might be from 16 percent to about 19.6 percent, still a substantial increase.

No doubt Colombia's distribution would also look worse if capital gains could be taken account of. The distribution of those earnings would, like other income, be more unequal than in the U.S. But their relative importance might be less so the increase in inequality from their inclusion would probably be less than in the U.S.

2 It is true, though, that income per member of the labour force rose somewhat faster, at about 1.9 percent. 
to a renewed worsening of the distribution. Two major indicators of low income group welfare are the agriculture wage rate and the construction worker wage rate. The latter, as discussed elsewhere, ${ }^{1}$ seems fairly clearly to have fallen during this period while the agricultural wage rate tended to remain rather stable and the blue collar wage rate in manufacturing to increase more slowly than before--at about 2.2\%--over 1966-70. ${ }^{2}$ Meanwhile the white collar wage in manufacturing rose by about $3.2 \%$ per year.

Another phenomenon which seems in the past to have been associated with worsening distribution is a decrease in proletarization in the commerce sector; when wages in commerce establishments, including rather small ones, were rising rather rapidly over the 1954-67 period, the share of paid workers in the total labour force rose from 30.8 to $35.7 \%$. But since 1967 it appears to have fallen once again. ${ }^{3}$

As observed in Table No. 7, the pure labour share of net domestic income does appear to have started down again about 1967 after having been relatively constant for a decade; this is true in both agriculture and in non-agriculture. The human capital share began to move up again, while the physical capital share remained essentially stable at about $35 \%$; it had edged down a little over the previous decade. If redistribution in the last three years has been associated with a decreasing unskilled labour share but an increasing human capital share, then given the considerable expansion

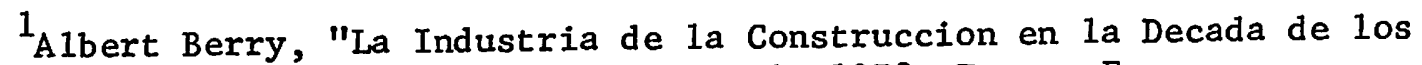
Sesenta," Economia Colombiana, No. 92, April, 1972, Tercer Epoca.

2 Figures from DANE, Boletin Mensual de Estadistica, various copies. Since no cross checks with other sources have been possible for this recent period, the data are somewhat less solid than for the previous period.

${ }^{3}$ See Albcrt Berry and Christina Lanfer, "Towards an Interpretation of the Rapid Post-War Growth of Services in Urban Colombia," mimeo, 1972. 
in primary education over the preceding years, it cannot be concluded without further analysis that a worsening of income distribution has occurred. The share of population in the agricultural worker/construction worker categories has been falling. An important question becomes that of how distribution has been changing within the income ranges categorized by some human capital. 1

\section{Two Caveats: Further Considerations}

It is worth guarding against the impression that a "worsening" or "bettering" of the distribution of income in the national accounts sense (or even including appreciation of capital assets) is the same as a worsening or bettering of welfare distribution. A number of somewhat quantifiable elements not taken into account satisfactorily in national accounts enter into the determination of welfare, along with a number of essentially non-quantifiable (at least by economists) components. In the former category fall education, public services, health, and same other facets of welfare. Discussions elsewhere have indicated that education, health, and housing have all tended, over the last several decades, to improve in some respects even for the lower income members of thepulation; $^{2}$ the distribution of education appears not to have worsened and perhaps to have improved over time, and almost certainly this is true for the distribution of health. ${ }^{3}$ with respect to housing not enough information is

$1_{\text {Had the physical capital share been rising one might more directly }}$ have concluded that this would imply worsening of the family or personal distribution, since physical capital is probably more unequally distributed than human capital.

2A. Berry, "A Review of Development in Colombia Since World War II," mimeo, 1971 .

${ }^{3}$ Miguel Urrutia, "Politica Fiscal y Distribucion del Ingreso en Colombia," mimeo, 1971. 
available to come to any conclusion. (And in any case this one may be argued to be more completely taken account of in the national accounts measure of income than is health or education.) To summarize, one cannot yet make any confident generalizations about how distribution of welfare has changed over the periods considered here, even those elements of welfare which are essentially economic as opposed to social or political.

With respect to the hypothesis cited above that periods of rapid growth correspond to periods of worsening distribution and vice versa, it should be noted that even were this an accurate description of historical relationships, and even had they in fact been causal (from rapid growth to worsened distribution, or the opposite) this conclusion would not imply as much pessimism as might appear on the surface; many aspects of the process of development in Colombia and the nature of policymaking suggest that a number of promising policy alternatives, which could have both improved distribution and speeded up the growth rate have, for one reason or another not been given serious consideration. In other words, it appeared that given the decision making and power distribution matrix characterizing Colombia over the period under discussion, the negative relation between growth and distribution might have been expected; but the fact that it occurred by no means implies that it is a necessary relationship; there are even strong arguments to the effect that to attain really rapid growth is impossible without some improvement in income distribution, since the policies characterizing rapid growth periods and helping to worsen the distribution of income were in fact not optimal policies.

\section{Income Changes of Lower Income Groups and Their Relationship} to the Overall Rate of Economic Growth

In the more pessimistic literature on economic development, one sometimes sees it argued that lower income groups in developing societies tend 
to suffer absolute declines in their income and welfare levels (we call this Hypothesis 1); it is also argued (Hypothesis 2) that rapid growth has sometimes not only led to a worsening of distribution--apparently consistent with the record in Colombia--but also lowered the absolute income level of the lower income group; this latter hypothesis could imply that the results of a faster growth rate would be a lowering of the welfare of the society as a whole if one places sufficient weight on the lower income groups.

The first hypothesis, that major groups have suffered decreasing absolute incomes over substantial periods of time, receives little support from the colombian statistics. The only group analyzed for which the argument could be taken seriously are the agricultural workers, whose reported real wages appeared in the mid-60's to be only at about their mid-30's level. But, as mentioned earlier, it appears that the figures for the mid-30's were probably well above those of, say, the 20's, so that over the longer run and certainly over the course of the 20th Century, this group has seen a substantial income increase. The same goes for such other unskilled groups as construction workers, artisans, small scale commerce workers, and so on.

The more interesting question in the Colombian context is whether these groups benefit or are harmed by rapid economic growth. Colombia provides a good laboratory experiment in terms of fairly lengthy periods of slow and of rapid income growth; if the hypothesis is alleged to be related to output (as opposed to income) growth--and this might be the more normal version of it--then the laboratory is less useful, since there were smaller

${ }^{1} \mathrm{~A}$ conclusion supported by a calculation made by McGreevey. (William P. McGreevey, An Economic History of Colombia 1845-1930, Cambridge, Cambridge University Press, 1971, p. 132.) 
fluctuations. They were, however, in the same direction as those of per capita income, so we can more or less freely take the period 1934-56 as one of particularly rapid growth, 1956-66 as one of slow growth and 1966 and on as one of rapid growth. Unfortunately adequate figures on the income of several of the low-income sub-groups is not available to permit an overall comparison across these periods, but it is interesting to note what happened to agricultural workers, construction workers, workers in smallscale manufacturing plants (but not artisan workers per se), workers in commerce, and maids. One might well hypothesize that different groups would be affected in different ways by the growth since some, like small-scale manufacturing, could by hypothesized to be essentially in competition with the dynamic sectors, while construction workers (at least as long as construction technology is fairly stable--as it appears to have been in Colombia) and maids might be thought to be complementary. Table 9 summarizes some of the relevant information. For several groups actual decreases in income do appear to have occurred over the first period of relatively rapid growth. Although manufacturing blue collar workers as a group had income increases almost as fast as the economy wide average, it is not improbable that the small scale firms did not share so successfully in the growth; were this the case, then the only group listed here with a gain close to the overall average would be maids. ${ }^{1}$ Almost all of the categories had increases equal to or above the average during the slow growth period 1956-66 and all those for which comparisons are possible did better in that period than in either of the fast growth periods.

Who provide a service clearly complementary with the success of high income people. 
Table 9

Annual Percentage Income Change of Selected Occupational Groups, Compared Across Periods of Slow and Fast

Overall Income Growth

Occupational

Group

Agricultural Wage Labours

Unskilled

Construction Workers

(Bogota) $1935 \pm-1956$

(fast growth)

-0.70 to $+0.37^{a}$

sma11 decrease sma11 increase ${ }^{d}$
Period 2 1956-1966

Period 3 1966-1970

(slow growth)

$1.5^{b}$

3.8

$-2.0 \pm^{e}$

Blue Collar Manufacturing Workers
Total
$2.18-2.36^{\mathrm{f}}$
4.8
Smal1 Plants (< 25 workers) n.a.
$3.3^{\mathrm{g}}$
Large Plants ( $\geq 25$ workers) n.a.
$3.9^{g}$
Commerce Workers
A11
Smal1 Establishments
( $<5$ workers)
$1.3^{\text {h }}(1954-1967)$
$1.2-2.9^{j}(1954-1967)$

$2.0^{\mathrm{g}}$

n.a.

n.a.

Food Retailing

decrease ${ }^{\mathrm{m}}$

Maids

substantial increase
(Bogota only)

3.9 (Bogota on 1y)

n.a.

Average Growth of Income

$2.76^{k}$

$1.68^{\mathrm{b}}$

4.04

Per Member of the Labour Force 


\section{Footnotes}

${ }^{a}$ See Table 1 for discussion. The upper figure shown is the more probable.

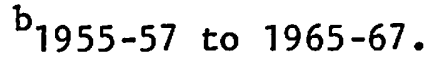

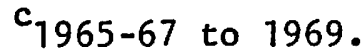

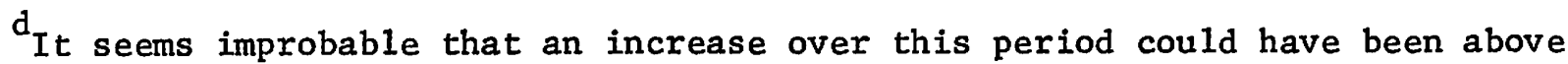
say $1 \%$ per year; it could well have been less.

e 1965-67 to 1969-71. See Berry, "La Industria de 1a Construccion ..." op. cit., p. 25 .

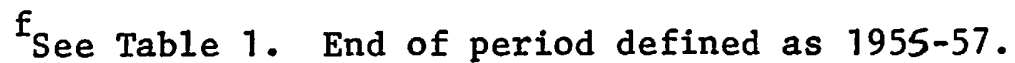

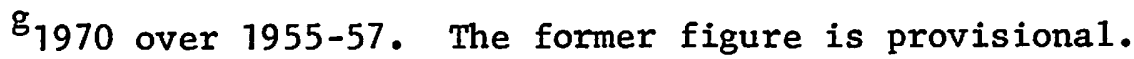

F From Berry, "The Relevance and Prospects ..." op. cit., p. 3 and p. 32.

hrom Berry "Urban Labour Surplus and the Low Skill Service Sector: The Case of Colombia," mimeo 1973.

$j_{\text {From Table } 3 .}$

$k_{1934-36}$ to $1955-57$.

mda11, op. cit. Based on Bogota data. It is interesting to note that Udall's figures (large store clerks) indicate a considerable increase over 1945 to 1954-58 so unless there was a drop in the period"mid-thirties to 1945", a considerable increase must have occurred over the period as a whole.

"Uda11, op. cit. There is some uncertainty here since Udall estimates the whole of the increase in question to have occurred before 1945, a period during which his sources of information were not internally comparable. 
It should be obvious that these results must be interpreted with caution; ${ }^{1}$ it would be a contradiction of terms to argue that in the long run the welfare of low income groups can be advanced by preventing growth. But they do raise questions. If in fact growth has been causally related to worsening distribution, can the nature of growth be altered so that this price need not be paid? Or can alleviatory institutions be developed to lower the costs of growth and thus provide "social lubrication" for the process? The evidence is suggestive enough to call for additional empirical work to permit more confident accept or rejection of the relationship which seems to have surfaced here, and theoretical work on the mechanisms which may have generated it.

${ }^{1}$ Apart entirely from the fact that the observed relationship under discussion may be spurious. Other factors were no doubt important in determining some of the income changes in question; the violencia for example may have helped push people into low income urban jobs towards the end of the first period, contributing to the bad experience of some of the groups. 
Table A-1

Real Wage Indices (Five Year Moving Averages) of Government Employees

\begin{tabular}{|c|c|c|c|c|c|}
\hline$\because$ & Year $^{1}$ & $\begin{array}{c}\text { National } \\
\text { Government }\end{array}$ & $\begin{array}{c}\text { Departmental } \\
\text { Government }\end{array}$ & $\begin{array}{l}\text { Municipal } \\
\text { Government }\end{array}$ & $\begin{array}{c}\text { Weighted Average } \\
\text { of Three Government } \\
\text { Levels } \\
\end{array}$ \\
\hline \multirow{5}{*}{$\boldsymbol{i}$} & & $(1)$ & (2) & (3) & $(4)$ \\
\hline & 1.924 & $59.9^{a}$ & $59.9^{a}$ & $39.4^{a}$ & $55.8^{a}$ \\
\hline & $\begin{array}{l}\text { 1939 } \\
1940 \\
1941 \\
1942 \\
1943 \\
1944 \\
1945\end{array}$ & $\begin{array}{l}69.5^{a} \\
76.5^{a} \\
86.13 \\
86.18 \\
88.83 \\
91.13 \\
89.69\end{array}$ & $\begin{array}{l}72.3^{a} \\
77.7^{a} \\
75.94 \\
75.41 \\
73.65 \\
70.93 \\
68.85\end{array}$ & $\begin{array}{l}56.9^{a} \\
61.1^{a} \\
58.00 \\
57.38 \\
56.26 \\
54.74 \\
55.50\end{array}$ & $\begin{array}{l}68.3^{a} \\
73.9^{a} \\
76.43 \\
76.11 \\
76.24 \\
75.77 \\
74.52\end{array}$ \\
\hline & $\begin{array}{l}1946 \\
1947 \\
1948 \\
1949 \\
1950\end{array}$ & $\begin{array}{l}90.43 \\
93.63 \\
95.32 \\
93.54 \\
91.48\end{array}$ & $\begin{array}{l}67.31 \\
67.84 \\
68.21 \\
69.04 \\
77.76\end{array}$ & $\begin{array}{l}58.44 \\
61.44 \\
61.92 \\
63.60 \\
66.34\end{array}$ & $\begin{array}{l}74.78 \\
76.88 \\
77.80 \\
77.75 \\
80.96\end{array}$ \\
\hline & $\begin{array}{l}1951 \\
1952 \\
1953 \\
1954 \\
1955\end{array}$ & $\begin{array}{l}89.16 \\
88.38 \\
88.82 \\
91.66 \\
95.76\end{array}$ & $\begin{array}{l}80.90 \\
81.74 \\
84.04 \\
85.88 \\
80.00\end{array}$ & $\begin{array}{l}68.28 \\
69.04 \\
74.26 \\
79.10 \\
80.50\end{array}$ & $\begin{array}{l}81.68 \\
81.86 \\
84.00 \\
86.84 \\
86.40\end{array}$ \\
\hline$\stackrel{1}{i}=$ & $\begin{array}{l}1956 \\
1957 \\
1958 \\
1959 \\
1960\end{array}$ & $\begin{array}{r}98.54 \\
98.94 \\
100.50 \\
101.14 \\
102.16\end{array}$ & $\begin{array}{l}80.58 \\
81.64 \\
83.68 \\
87.40 \\
94.36\end{array}$ & $\begin{array}{l}81.84 \\
85.10 \\
87.56 \\
89.44 \\
95.64\end{array}$ & $\begin{array}{l}88.02 \\
89.25 \\
91.18 \\
93.30 \\
97.74\end{array}$ \\
\hline & $\begin{array}{l}1961 \\
1962 \\
1963 \\
1964 \\
1965\end{array}$ & $\begin{array}{l}106.38 \\
107.89 \\
108.07 \\
110.43 \\
109.93\end{array}$ & $\begin{array}{l}99.10 \\
104.1 \\
108.12 \\
108.54 \\
108.08\end{array}$ & $\begin{array}{l}101.36 \\
103.22 \\
106.01 \\
108.25 \\
109.39\end{array}$ & $\begin{array}{c}102.46 \\
105.44 \\
107.68 \\
109.24 \\
109.08\end{array}$ \\
\hline
\end{tabular}

Sources and Methodology for Table A-1

The source for the nominal wages on which the data of this table are based is, in the majority of years, the Anuario General de Estadistica. For years in which information could not be found in the Anuario data from the publication Estadisticas Fiscales y Administrativas was used. The published data (in both cases) gave the total wage cost and the number of permanent employees. Various types of bias may come from assuming that the ratio of these two figures measures the wage rate, as for example when in different years a different share of the wage bill

Ggos to temporary workers; also it is true that the apparent noninclusion of fringe benefits in the labour cost data introduces a negative bias over time, since fringe benefits have been an - increasing share of total remuneration.

- To convert the nominal figures to real ones the following indices were used; (1) 1954-6: the national white collar cost of living series was used in the case of the municipalities and departments and the corresponding Bogota series to deflate the national government salary series (given that a large part of the national government employees live in Bogota). (2) 1946-54: the Bogota white collar cost of living series was used (no national series was available over this period). (3) 1937-46: a blue collar Bogota cost of living series was used; not even a Bogota white collar series was available during this period. It is clear that the methodology used to convert the nominal salaries to real ones can introduce a variety of weaknesses in the series. 
Table A-2

Income Trends by Occupations

(1958 pesos per year)

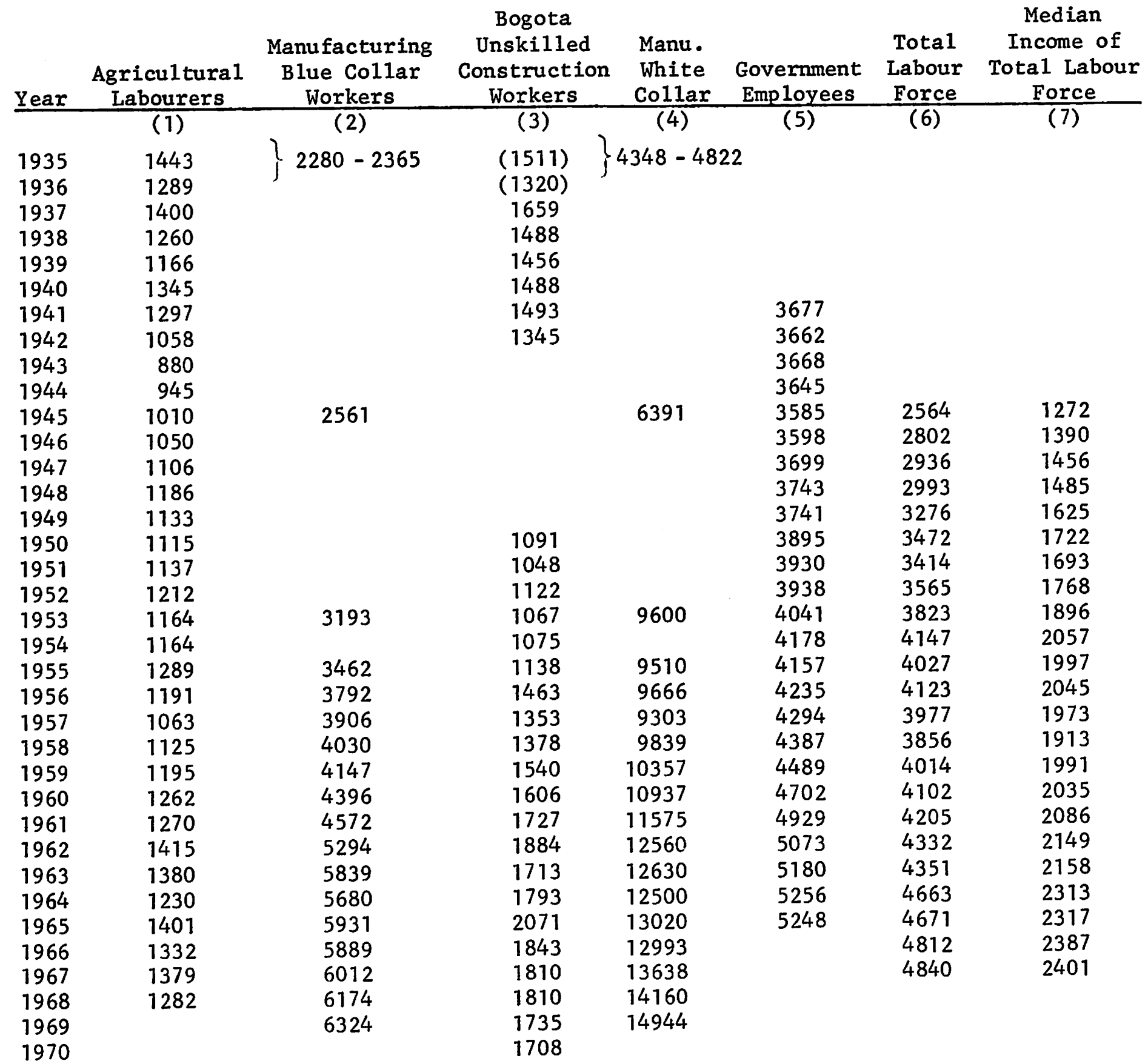

( ) Indicates rough estimate. 
Sources and Methodology for Table A-2

Column (1) is based on data compiled in A. Berry, The Development ... op. cit., statistical appendix.

Columns (2) and (4) are from A. Berry, "A Review of Development in Colombia Since World War II," mimeo 1971.

Column (5) is from the sources cited in Table 1.

Column (6) is from A. Berry, "A Review ... " op. cit., Table A-1.

Column ( 8 ) is simply column (7) times 0.496 , a coefficient based on the observed relationship between the median and the mean in 1964 when estimates of both were available; clearly this ratio is not constant over time so this column gives only a rough estimate of the true median.

Column (3)'s sources are cited in Table 2. 